\title{
Bound To Be? Bare and Partitive-Marked Noun Phrases in Romance Languages and the Emergence of Prominence-Conditioned Patterns
}

\author{
Hagay Schurr
}

$\mathbf{1}$

Introduction

"Partitive" morphemes (e.g., adpositions, articles or case) and bare nouns in many languages are intuitively similar in denoting some kind of indefiniteness. In Romance languages, partitive-marked nouns and a class of bare nouns share a core context of occurrence and indefinite interpretation (Körner 1981; Stark 2005). ${ }^{1}$ Certain non-countable, substance- or abstract-denoting nouns may or must occur with a "partitive article" in some languages, but remain bare in other languages, as in French (1a) and Spanish (1b) respectively (see Section 2.4.4). ${ }^{2}$

a. French

$$
\text { Je=bois du café }
$$

1SG=drink.PRS.1SG PA.M.SG coffee

'I drink coffee.' (in general)

b. Spanish
Bebo
café
drink.PRS.1SG coffee
'I drink coffee.' (in general)

The same morphological distinction extends to plural indefinites and hence to countable nouns (Section 2.4.4) (Carlier and Lamiroy 2014). For instance, the French indefinite plural may have a non-specific reading in (2a), while its Span-

1 See Dobrovie-Sorin, this volume, for a comparison between French plural indefinites introduced by a "partitive article" and bare nouns across languages. Partitive-markers in some Germanic varieties are discussed in Strobel and Glaser, this volume.

2 An anonymous reviewer notes that (1a) has another interpretation: 'I drink some of the coffee' in the context of a specific receptacle of coffee. While this reading is available, it is not equivalent to the Spanish bare object clause in $(\mathrm{lb})$. 
ish counterpart is bare yet again $(2 \mathrm{~b}) .^{3}$ The ensuing discussion applies to both countable and non-countable nouns in Romance languages.

(2) a. French

Je=vois *(des) étudiants dans le bâtiment.

1SG.SBJ=see.PRS.1SG PA.PL students in the building

'I see (some) students in the building.' (Stark 2007, 50)

b. Spanish

Veo (a) unos estudiantes en el edificio

see.PRS.1SG DOM some students in the building

'I see (some) students in the building.' (Stark 2007, 50)

The term "partitive" has two major uses. Genuine partitive patterns denote part-whole relations between a referential whole and its part ("drink some of this coffee"), but they recurrently serve as diachronic sources for a second use of "partitive", namely, parti-generic expressions. The latter refer to indefinite quantities - or subsets of a generic whole - and form part of the domain of indefiniteness (Luraghi 2012). The difference between both types of partitives lies in whether the superset whole is a referential entity or a whole genus (Ihsane 2005, 2008; Kabatek 2014; Koptjevskaja-Tamm 2009; Stark 2005). ${ }^{4}$

Unlike partitive-marked nouns, bare nouns lack determiner morphology by definition (Diez 1844; Kabatek and Wall 2013; Stark 2009). However, bareness itself is a means of determination in its recurrent association with indefinite semantics.

Areally and phylogenetically, "partitive articles" (henceforth PA) are generally confined to some northern Romance varieties of France and Italy (GalloRomance, Italo-Dalmatian Raeto-Romance) (Körner 1981; Bossong 2008) with bare noun arguments more frequently used in southern Romance varieties. ${ }^{5}$ However, much of the fine-grained details remain debatable or unaddressed. The phylogenetic distribution of bare and partitive deserves careful scrutiny under a family-level comparison of all genealogical sub-branches of Romance.

3 The differentially $a$-marked variant of which yields a specific reading (Stark 2007).

4 The exact semantic analysis of bare/partitive pairs as in (1) is not at issue. In the literature, they are analyzed as kind- or property-denoting nouns or as attributive or predicative expressions (cf. Beyssade 2011; Dobrovie-Sorin and Laca 2003).

5 The term linguistic variety relates to linguistic variation irrespective of its motivation, be it determined diatopically (across space), diaphasically (in register across socially-based contexts) or otherwise. Variety rather than language is also the unit of reference used in the synchronic comparative study (Section 4). 
Additionally, the syntactic distribution of the PA across grammatical relations and clause types remains subject to debate, as does the range of noun classes with which the PA is obligatory (e.g., substance-denoting, plural countable nouns) (Luraghi 2012; Stark 2007).

To broaden the empirical basis and contribute to our understanding of the bare/partitive distinction, previous research has drawn a line between PA and similar structures. In adnominal syntax, Differential Object Marking (Dом) is one candidate for comparison (Section 2.2.1). The label of DOM describes the morphological marking of direct objects, often determined by their referential properties and pragmatic properties (Bossong 1982, 1985; Dalrymple and Nikolaeva 2011). ${ }^{6}$ Although the comparability of DOM to PA is far from unanimously accepted (cf. Bárány 2018; De Hoop and Malchukov 2008; Haspelmath 2018; Luraghi 2012, for implicit or explicit objections), they are often mentioned in tandem since they tend to mark referents on opposite ends of "prominence" or "individuation" scales, including such properties as definiteness ( \pm definite), animacy (human $>$ animate $>$ inanimate) and countability $( \pm$ countable). The higher a referent ranks in such properties, the more prominent it is (Hopper and Thompson 1980; Aissen 2003). While the PA and bare nouns mark typically non-prominent referents, DOM tends to mark prominent referents (Seržant and Witzlack-Makarevich 2018). Unlike indefinite-referring (and non-specific, mass- or plural-denoting) PA, patterns of dative-syncretic Dом in several southern Romance varieties apply at least to inherently definite direct object referents such as personal pronouns or proper names (3) (Rohlfs 1971; Iemmolo 2010).

\section{(3) Spanish}

$$
\begin{aligned}
& L e_{i}=v e o \quad a \quad \text { Jesús Soria } \\
& \text { 3SG.ACC=see.PRS.1SG DOM Jesus Soria } \\
& \text { 'I see Jesús Soria.' (Española 2016a, Oral, 24/04/1999; henceforth CREA) }
\end{aligned}
$$

In those languages, direct objects that denote non-countable, indefinite referents most often remain bare, as in Spanish (1b).

In fact, DOM and PA serve as major typological determinants in Körner's (1987) typological distinction between two syntactic types in Romance languages. They are broadly indicative of a northern/southern divide with a number of grammatical correlates (Section 2.2.1).

6 "Inherence" is similar to the Animacy scale used earlier in analyzing Differential Subject Marking in ergative languages (cf. Bossong 1985; Silverstein 1976). 
While Körner's approach to the typological distinction was met with criticism, it is true that there is some distributional relation between PA and DOM (Bossong 2008). Therefore, when accounting for the bare/PA distinction, it may be informative to identify the distribution of both PA/bare nouns and Dом and their grammatical correlates, as well as other seemingly prominenceconditioned phenomena. I focus on such phenomena in the Romance clitic systems. To illustrate this, consider Spanish example (2) again (Spanish $l e_{i} v e o$ a Jesús Soria ${ }_{i}$ ' I see Jesus Soria'). There, the proper name direct object that is marked by a dative-syncretic DOM is coreferential with a dative-syncretic accusative clitic, $l e$, instead of the expected accusative lo (hence it is known as leismo). This pattern is observed in some Ibero-Romance languages, but not in northern Romance varieties (Fernández-Ordóñez 2001).

Diachronic studies on the bare/partitive distinction describe the shift from article-less Latin to Romance and the grammaticalization of both PA and bare nouns (Carlier and Lamiroy 2014; Kabatek 2013; Section 2.1). However, such descriptions cannot reveal why PAs grammaticalized in some languages but not others. Bossong (2008) makes a similar observation on Dом and argues that while pathways of grammaticalization are "universally available" (they are observed time and again in different languages), not all languages follow them. This is the classic problem of the initiation of language change. Why did the emergent property of PA grammaticalize in one language at a certain time but not another? This question becomes even more intriguing in view of the loss of adnominal partitives in some Old Romance varieties (e.g., Old Neapolitan, Old Portuguese) (Ledgeway 2012, 84; Rohlfs 1968, 115-119) and the emergence of DOM in some of them.

The aim of this paper is twofold: (i) to shed light on the distribution of the Romance bare/PA-marked nouns and (ii) to test how variation and change in Romance adnominal syntax (bare/PA and DOM) relates to variation and change in seemingly prominence-conditioned clitics.

I address the following questions:

i. What is the synchronic distribution of PA and bare nouns in Romance languages?

ii. How and when did PA and bare nouns and functionally-related phenomena emerge in Spanish and French?

I approach question (i) using a family-level representative sample of Romance languages (Appendix 2) (Section 4) and question (ii) using a comparative diachronic study in Spanish and French (Section 5).

My synchronic study corroborates previous observations on the distribution of PA in northern Romance, while providing empirical breadth with data from 22 languages from all sub-branches of Romance. A second result concerns the 
possible co-occurrence of PA, bare nouns and DOM in individual languages. Most importantly, there appears to be a negative relationship between the grammaticalization of PAs and that of DOM. To generalize, the greater the range of noun classes and syntactic structures in which PA becomes obligatory, the less extensive the use of Dом in the same language, if any. Similarly, languages with DOM rarely ever show PAs.

Based on the synchronic study, some languages show neither PA nor DOM, but only other seemingly prominence-conditioned clitics. This leaves open the question of whether such languages have never grammaticalized PA or have lost it. If this question is resolved, it may shed some light on the processes that led to the current distribution of bare and PA in Romance languages.

In the diachronic part of this study, I examine the case study of Medieval Spanish and French (12th-16th centuries) (Section 5). We already know that French has a PA, while Spanish does not. Did Spanish ever lose a PA or did it never grammaticalize? ${ }^{7}$ By conducting a diachronic study on the emergence of PA and related structures in adnominal and clitic morphology (e.g., DOM, partitive clitics, leísmo), we may be able to answer this question and shed light on their current distribution. My main findings are that:

i. Medieval French gradually grammaticalized PA patterns between the nth and 16 th centuries.

ii. Spanish showed some variation between bare nouns and PA with substance-denoting nouns between the 13th and the 16th centuries.

iii. Medieval Spanish gradually grammaticalized Dom between the 13th and the 16 th centuries.

iv. The Medieval French corpus showed no use of Dom.

v. Partitive clitics grammaticalized in Old French (11th-13th century) and are relatively frequent throughout the corpus (11th-16th centuries).

vi. In Old Spanish, both leísmo and genuine partitive pronouns are documented, though partitive pronouns are relatively infrequent.

This paper corroborates previous findings regarding the distribution of PA and bare nouns in Romance languages (Körner 1981; Stark 2007), while adding empirical breath based on a representative family-wide sample and several related phenomena. The historical analysis of Spanish and French shows that prominence-conditioned clitics grammaticalized before PA and DOM. It also reveals stark differences in variation and change to the relative frequency of third person clitics in both language throughout the period. I will argue that these results, raise the possibility that all else being equal, early variation in

7 Gerards and Stark, this volume, also discuss this issue. 
the relative frequency of clitics - including prominence-conditioned tokenscould affect the tendency of a language to grammaticalize PA or not (and then possibly grammaticalize DOM).

This paper is organized as follows. Section 2 reviews the theoretical and empirical background regarding the bare/partitive distinction (Section 2.1) and its place in a system of prominence-based nominal classification broadly construed (Section 2.2). Section 3 lays out the main questions addressed and an overview of the two studies conducted to answer them. Sections 4 and 5 report the methods, result and discussion of the synchronic and diachronic study respectively. Section 6 concludes with a general discussion.

\section{$2 \quad$ Theoretical and Empirical Background}

\section{1 "Partitive Articles" and Bare Nouns}

As mentioned in Section 1, the term "partitive" refers to syntactic structures that denote part-whole relations between a referential entity-denoting whole and its part, and which may grammaticalize into morphemes that mark part-whole relation between whole genera and their parts ("drink some of this coffee" as opposed to "drink some coffee") (see Section 1) (Kabatek 2014; KoptjevskajaTamm 2009; Luraghi 2012). As they grammaticalize, such "partitive articles" (PAS) in Romance languages are used more frequently and may become obligatory markers of indefiniteness. For instance, the juxtaposition of the ablative preposition $d e$ and the definite article in Old Italian (4a) can only have a genuine partitive reading. However, in contemporary Italian, such partitive phrases may also have an indefinite, parti-generic reading $(4 \mathrm{~b}) .^{8}$

(4) a. Old Italian

Ela mançà del pomo qe li un 3SG.F eat.PST.3SG of.the.M.SG apple that 3SG.DAT give.PST.3SG a serpente.

snake

'She ate of the apple that a snake gave her.' (Uguccione da Lodi, early 13th century, cited in: Luraghi 2012, 15)

8 The availability and distribution of "partitive articles" varies in regional varieties of Italian and Italo-Romance languages (see Giusti, this volume, for a detailed account). For a discussion on the problematic position of Italian in the bare/partitive typology, see Stark (2007). 
b. Modern Italian

Ho bevuto della birra

have.PRS.1SG drink.PTCP PA.F.SG beer

'I drank some beer.' (Storto 2003, 317)

Bare nouns simply lack determiner morphology so they appear in their bare form and are often referentially similar to PA-marked nouns.

In terms of their synchronic distribution, it is known that PAs occur in northern Romance varieties, but not in southern Romance varieties (Körner 1981; Bossong 2008). However, the details of their syntactic distribution in individual languages (across grammatical relations and clause type) remain debatable and so do the details of their occurrence and distribution in lesser studied Romance languages.

Several studies focused on the grammaticalization of the PA and the "negative grammaticalization" of bare nouns (Carlier and Lamiroy 2014; Kabatek 2013). Grammaticalization is a process of language change that yields new grammatical structures from lexical or grammatical sources (Boye and Harder 2012; Meillet 1912). As linguistic units grammaticalize, they shift from pragmatic conditioning to semantic and finally syntactic conditioning. As grammaticalizing units become entrenched (Langacker 1987), their meaning often undergoes generalization and abstraction from lexically-informative to grammaticallyinformative, a process known as "semantic bleach" (Bybee 20o6; Sweetser 1988). The change in partitive phrases in some languages from denoting parts of specific, referential entities to parts of generic and abstract whole is an example of grammaticalization. ${ }^{9}$

Carlier (2007) and Carlier and Lamiroy (2014) note that the PA emerged in the shift between Old French (11th-13th centuries) and Middle French (14th-

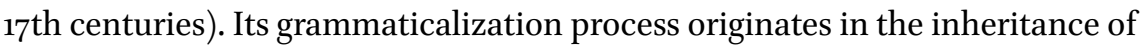
the Latin preposition de into Old French as a syncretic marker of source (spatial and non-spatial) and genuine partition of determinate wholes ("eat from this bread") (Shift 1 and 2 in Figure 3.1). Only in Middle French is it extended to the marking of indefinite groups of individual ("aggregate plurals") (example (2a): French je vois *(des) étudiants dans le bâtiment, 'I see (some) students in the building.'). At this point it enters the paradigm of articles, and gradually extends to be used with indefinite substance-denoting nouns and finally abstract-denoting nouns in the 16 th century.

9 Although Campbell (2000) deconstructs grammaticalization to nothing more than the sum of other "atoms of language change", understanding the process remains useful in shedding diachronic light on emergent morpho-syntactic properties. 
Spatial source $>$ non-spatial source $($ Shift 1$)>$ genuine partition $($ Shift 2$)>$ indefinite aggregate plural (Shift 3 ) > indefinite substance-denotation $>$ indefinite abstract denotation (Shift 4 )

FIGURE 3.1 Grammaticalization of the "partitive article" in French

Stages 1 and 2: The Latin ablative preposition de extends from spatial source marking to marking other source-like adjuncts (e.g., lineage, temporal meanings). Then, it is extended to denoting genuine partition of a contextually defined partition set. This process starts with objects of consumption verbs ('drink', 'eat') with which de extends from adjunct-marking to marking of argument. This state is inherited to Old Romance, including Old Italian (4a) and Old French (5).

\section{(5) Old French}

Dunc but del vin ${ }_{i}$ qui $l_{i}^{\prime}=a d \quad$ el so drink.PST.3SG of.the wine REL.SBJ 3SG.ACC=have.PRS.3SG the champ trové

field find.PTCP

'So he who found the wine in the field drank from it.' (Guill, 25, v. 524, 12th century, ms. 13th century Cédille, 2016; henceforth B FM)

Stage 3: Once de-based morphemes extend to marking arguments, the PA extends beyond the class of consumption verbs at the expense of previously accepted bare noun contexts, e.g., in marking indefinite groups of individuals (aggregate plurals) (see example 2a).

Stage 4: PAs obligatorily mark substance-, kind-denoting nouns before abstract nouns in 16th century Middle French. Earlier variation in marking abstractdenoting nouns is observed in the $15^{\text {th century. }}$

In line with this grammaticalization process, while genuine partitive phrases are specificity-restricted in that their partitioned whole must be specific, fullfledged PA marks non-specific plural indefinites before its extension to nonspecific, non-countable and abstract nouns. ${ }^{10}$

10 For a discussion of PA marked specific plural indefinites in French, see Ihsane, this volume. 
To account for the occurrence of this shift in northern Romance, but not in southern Romance, the authors indicate that word order tendencies appear to correlate with the grammaticalization or not of certain morphemes, including the PA. Their account appears to hold, but there may be other typological factors which correlate with the grammaticalization and resultant distribution of PA and bare nouns.

Stark (2005) focuses on four languages, two from southern Romance (Spanish and Romanian) and two from northern Romance (Italian and French). She proposes that in the shift from Latin to Romance, a system of nominal classification was lost, obscuring the cognitively and communicatively important distinction between "contoured", individual-denoting nouns and "non-contoured" substance-denoting nouns. As part of this change, languages that have all but lost the Latin neuter gender (e.g., French and Italian) found "functional compensation" in the emergence of PA.

Assuming with Stark that nominal classification is central to the bare/PA distinction, Section 2.2 lays out in more detail what I mean by nominal classification and its relation to referential properties of nouns in terms of prominence.

\subsection{Nominal Classification and Prominence}

Nominal classification systems generally share the primary function of classifying referents into semantically coherent groups (Fedden and Corbett 2017; Senft 2007), indicative of physical properties or degree of prominence, based on number, animacy or shape (Aikhenvald 2017; Seifart 2010), also known as individuation (Hopper and Thompson 1980). In addition to their classifying function, nominal classification systems also have other secondary functions, such as tracking the reference of nouns and other referential term (Greenberg 1978,78 ). This function comes "for free" since classification to distinct groups that indicate semantic and grammatical properties narrows down the set of alternative referents.

In the typological literature, prominence is a cluster concept based on several pragmatic and referential scales (Aissen 2003; Seržant and Witzlack-Makarevich 2018; Haspelmath 2019). For instance, Haspelmath's $(2018,5)$ definition of prominence (A) combines both referential (A.i) and discourse-based properties of referents (A.ii).

A. Scales of Referential and Discourse Prominence

(i) Inherent prominence
a. Person: 1st, 2nd $>$ 3rd
b. Nominality: person form (free/bound) $>$ full nominal
c. Animacy: human $(>$ animal $)>$ inanimate 
(ii) Discourse prominence

a. Specificity: definite (>specific indefinite) $>$ nonspecific indefinite

b. Givenness: discourse-given $>$ discourse-new

c. Focus: background $>$ focus

This view of prominence as a cluster of scales that are essentially extra-grammatical and pre-theoretical (Haspelmath 2010) (e.g., phrased in terms of semantic scales) is couched in usage-based approaches whereby grammatical categories are by and large emergent properties of language (Haspelmath 2015). Hence the desideratum of distinguishing language-specific descriptive concepts from comparative concepts with the aim of facilitating cross-linguistic comparison with a single extra-grammatical yardstick.

Prominence thus construed can be used in considering the Romance PA in its grammaticalization (Carlier and Lamiroy 2014) and resultant distribution (Stark 2005). Addressing the emergence of the PA, Carlier and Lamiroy demonstrate that the genuine partitive of Old French exclusively applies to the partition of a definite, specific whole that is typically a substance-denoting, inanimate object of consumption verbs (e.g., Old French delvin 'of the wine' in example (4), Section 2.1). With the advent of the PA in Middle French, the definiteness restriction is relaxed, and PA-marking extends to wholes that are not identifiable to the addressee, including non-specific indefinites. Then, the animacy scale comes into play as the PA extends to the partition of indefinite plurals, including groups of human- and animate-denoting nouns. At this point, restrictions on specificity of the partitioned whole are relaxed, paving the way for the PA to extend to non-specific indefinite and inanimate, substance-denoting nouns in the 16th century. This restriction still affects the distribution of partitive phrases in Spanish where PA did not grammaticalize and partitive morphology applies to specific genuine partitives, not to non-specific parti-generic expressions. This is one way in which Stark's (2005) distributional observation that northern Romance languages tend to mark non-prominent arguments with PAs, while southern Romance languages tend to use bare nouns in the same contexts may be couched in terms of prominence scales.

Other syntactic phenomena that were previously described in terms of prominence or some of its component referential/pragmatic scales were also studied to some extent in relation to PA. This includes DOM (Section 2.2.1) and several clitic patterns in Romance and beyond, generally known as Differential Object Indexing (Section 2.2.2). 


\subsubsection{Differential Object Marking}

Differential Object Marking (DOM) designates the morphological marking of direct objects based on grammatical conditions, often related to referential and pragmatic properties of arguments (Bossong 1982, 1985; Dalrymple and Nikolaeva 2011; see Section 1). These properties make their referents more prominent (and accordingly more frequently marked as direct objects, see Haspelmath 2018) or less so. Accordingly, both DOM and PA are sometimes considered as means of prominence-conditioned nominal classification (Stark 2005; Seržant and Witzlack-Makarevich 2018). Whether both are different types of DOM is a different question (see Luraghi 2012, for objections).

We have already seen that DOM tends to apply to prominent referents (e.g., specific, human-denoting) but not to non-prominent referents (e.g., non-specific, substance-denoting, Section 1). In Romance languages, we may distinguish two general types of DOM systems (Iemmolo 2010):

a. "Incipient DOM" is restricted to the most topical referents. It minimally marks free personal pronouns but may extend to proper names and kinship terms.

b. "Established Dом" systems extend Dом to become optional or even obligatory with a greater range of common nouns, typically including definite and specific-indefinite human-denoting objects.

To illustrate this, incipient Dom may mark dislocated pronominal object topics as in La Speza (Liguria, northern Italy) (5), though the marking of humandenoting common nouns is largely excluded in northern Italian varieties (Iemmolo 2010, 246).

(6) Italian (La Speza, Liguria)

$A$ te vogio vede subeto

DOM 2SG want.PRS.1SG see quickly

'I want to see You quickly.' (University of Padua, 2011 Syntactic Atlas of Italy, Questionnaire 1:75)

In Peninsular Spanish today, definite human-denoting common noun objects must be marked with DoM, illustrating an established Doм system (Cuétara Priede and Company Company 2014). However, this is the result of grammaticalization from an earlier, incipient Dom system of Old Spanish (13 th14th centuries), which marked personal pronouns, proper names and kinship terms (Meier 1948; Von Heusinger and Kaiser 2005). This restriction was gradually relaxed, and the percentage of marked human-denoting common noun object increased from $42 \%$ to $57 \%$ (13th-2oth centuries) (Cuétara Priede and Company Company 2014). We may mark the 16 th century as the cut-off point 
Free personal pronouns $>$ Proper name $>$ Kinship terms $($ singular before plural) $>$ Definite human common nouns $>$ Indefinite human common nouns (preferably specific) $>$ Animate referents $>$ Inanimate referents

FIGURE 3.2 Cline of topicality-worthiness/prominence

BASED ON HILL AND TASMOWSKI 2008; IEMMOLO 2010

between incipient and established Dom in Spanish when human-denoting common noun objects hit the $50 \%$ mark.

To illustrate a system that represents an intermediate stage in the shift from incipient to established DoM, Western Asturian obligatorily marks leftdislocated pronominal object with DOM (7a), but definite common nouns such as see el médicu ('the doctor') are only optionally marked in situ (7b) (i.e., in their expected post-verbal position in Subject-Verb-Object clauses, see the Asturian grammar of the Asturian Academy, Asturiana 2001, henceforth ALA). Therefore, the western Asturian DOM extends beyond incipient DOM in some northern Italian varieties, but it is less grammaticalized than that of Spanish, in which such object referents must receive DoM.

\section{(7) Western Asturian}

a. $A$ min tráxo=me en coche.

DOM 1SG traject.PST.3SG=1SG.ACC in car

'(S)he gave ME a ride.' (ALA, 352)

b. Baxó a buscar el/al médicu pa moi

descend.PST.1SG ALL search.INF the/DOM.the doctor for my

ma.

mother

'I went down to look for the doctor for my mother.' (ALL=allativesyncretic purpose marker) (ALA, 352)

It appears that the gradual extension of DoM from the most prominent personal pronouns (Meier 1948) to the obligatory marking of prominent common nouns is conditioned by the prominence scale of Focus (background/topic > focus) (Iemmolo 2010; Section 2.2). This process follows the topicality cline so that definite, human- and animate-denoting nouns are marked before specific indefinites (Figure. 2).

Since Dом typically almost never applies to non-specific referents nor, more importantly, to non-countable or abstract nouns, it is starkly different from 
the PA in terms of the prominence of marked nouns (Stark 2005, 134). ${ }^{11}$ But why should languages mark prominence in this way in the first place? One explanation is that prominence-conditioned morpho-syntax as in DOM is a low-frequency phenomenon in the sense that languages tend to more robust or "more special" adnominal marking of nouns whose referential properties are infrequently associated with certain semantic roles (Haspelmath 2018). Haspelmath argues that this frequency effect on grammatical coding can be explained based on predictability and coding efficiency (i.e., the less predictable associations tend to be marked, as in the case of DoM, cf. Hawkins 2012).

Does a language necessarily primarily mark only one type of prominence throughout its history? At least one example is known of a language that has lost an adnominal partitive in its history and saw the emergence of ром (e.g., Neapolitan, see Ledgeway 2012, 84). While this is not necessarily a causal relation, some diachronic relation between them may be possible.

Although PA and DOM do not necessarily share properties such as syntactic distribution and grammatical category (cf. De Hoop and Malchukov 2008; Luraghi 2012, for objections). They both contribute to referential and pragmatic classification of noun phrases, that is, to their classification based on prominence. In Romance languages, both adnominal markers (PA and DOM) are also negatively related in terms of their cross-linguistic distribution in Romance languages (Bossong 2008; Stark 2005). Therefore, when studying the distribution of PA and its grammaticalization, it may be informative to also observe the distribution and grammaticalization of DOM.

\subsubsection{Differential Cliticization (Differential Object Indexing)}

Similarly to PA and Dом, Differential Object Cliticization, better known as Differential Object Indexing (henceforth DOI) provides semantic and grammatical information on referents using bound person morphemes (e.g., clitics, affixes). Previous studies have already drawn a semantic line between the Romance PA and partitive clitics (Bossong 2008; Ihsane 2013; Pinchon 1972), which may also corefer with non-prominent expressions (e.g., inanimate, indeterminate substance-denoting nouns and quantificational expressions). However, DOI differs from PA or DOM in its main function, namely, to support the referential tracking of topical objects (cf. Schikowski and Iemmolo 2015). In example (8), the partitive clitic en purportedly facilitates reference-

11 Exceptionally individuated bare nouns (e.g., definite, singular, specific referents) in Dом are beyond the scope of this paper (for such patterns in Romance languages, see Mardale 2008; Von Heusinger and Chiriacescu 2009). 
tracking of a substance-denoting object (French la sangria, 'sangria') in topicmarking left-dislocation.

(8) French

La sangria $_{i}$ en fait $t^{\prime}=a s \quad$ découvert en the.F.SG sangria in fact $2 \mathrm{SG}(. \mathrm{SBJ})=$ have.PRS.2SG discover.PTCP in Espagne. $I l=e n_{i}=a \quad b u \quad$ vraiment tous Spain $3 \mathrm{M} . S \mathrm{SG}(. \mathrm{SBJ})=$ PART=have.PRS.3SG drink.PTCP really all les jours the days 'In fact, you discovered Sangria in Spain. He practically drank (of it) every day.' (G. Icor, S. Schwarz 2009, Bruxelles, Etienne, Jouin-Chadron, Lascar and Teston-Bonnard 2016; henceforth CLAPI)

As a reference-tracking grammatical device, such clitics perform a function long associated with nominal classification systems (Greenberg 1978). This alone favors the joint research on PA and partitive clitics among other DOI patterns on grounds of their commonalities with nominal classification.

Another DOI pattern of interest to non-prominence classification involves certain uses of the locative clitic in Romance languages. The French locative $y$ primarily corefers with spatial goals, but it also tends to cliticize other types of mostly non-human referents (Pinchon 1972). Hence its similarity to partitive clitics in the tendency to cliticize referents of lesser prominence down the topicality cline (Figure 3.2, Section 2.2). Such uses are documented in Old Spanish (Sánchez Lancis 1992) where nouns that denote locations or a group of humans in the same institution may be $y$-cliticized as indirect objects. It is the non-prominence of institution or group-denoting 'the abbey and monastery' (example (9)) that conditions its locative- rather than the expected dativecliticization, whereas dative-cliticized referents are typically prominent individual entities, capable of receiving property.

(9) Old Spanish

Toda esta por nombrada heredat do io al all this for numerous property give.PRS.1SG ISG the. DAT conuiento $e$ al monesterio et do $y$ mio abbey and the. DAT monastery and give.PRS.ISG DAT(.LOC) my cuerpo body 'I give all of this great property to the abbey and monastery [...], and I give it/them my body'. (Sánchez Lancis 1992, 803) 
This distinction resonates the conceptual distinction between "contoured" individuals and "non-contoured" mass-denotation(Stark 2005) or individuated and non-individuated referents (Hopper and Thompson 1980).

There are distributional reasons to examine such cliticizations when studying the bare/PA distribution. Although the occurrence of partitive clitics does not necessarily imply that of locative clitics or vice-versa (Benincà and Poletto 2005), both clitics occur in several mostly northern Romance languages, which also make the continuum in which we find PAs and related structures are found (Bossong 2008).

Yet another DoI pattern of interest is found in system of Spanish leista varieties, in which a dative-syncretic clitic is used when cliticizing humanor masculine-denoting direct objects (Echenique Elizondo 1981; FernándezOrdóñez 2001). We have already seen this in non-standard Spanish with dativesyncretic le being corefrential with a proper name (example (2), Section 1) repeated below as (10)). ${ }^{12}$

(10) Spanish

$$
\begin{aligned}
& L e_{i}=\text { veo } \quad a \quad \text { Jesús Soria }_{i} \\
& \text { 3SG.ACC=see.PrS.1SG DOM Jesus Soria } \\
& \text { 'I see Jesús Soria.' (Española, 2016a Oral, 24/o4/1999) }
\end{aligned}
$$

Distributionally, leismo is found in Ibero-Romance languages of the southern Italian group, but not in nothern Romance nor in other southern Romance phylogenetic branches (Fernández-Ordóñez 2001, 25-26).

The semantic contribution of leismo clitics is similar to that of dative-syncretic Dом in Romance languages (Bossong 1991; Fernández-Ordóñez 2001, 23). Moreover, Bossong $(1991,155)$ claims more strongly that leismo in northern Peninsular Spanish results from an analogical change due to dative-syncretic Dом. At any rate, the co-occurrence of dative-syncretic accusative in both adnominal and pronominal or clitic systems is attested in non-standard Spanish varieties with leismo and ром (8). For these reasons, it may prove instructive to consider leismo along with the abovementioned DoI patterns when attempting to account for the distribution of PA and DOM.

Due to the commonalities in prominence-conditioning between the abovementioned DOI patterns - partitive, locative and dative-syncretic clitics—and their adnominal counterparts (PA and DOM) and in view of their current dis-

12 Such examples with proper name direct objects may be considered ungrammatical (Llorente and Mondéja 1974, 36), but they are at least marginally acceptable (Gabriel and Rinke 2010, 68; Matthias Heinz, personal communication, 2017). 
tribution in Romance languages, I add them to the typological toolkit in this study on the bare/PA distinction.

\subsubsection{Two Hypothetical Avenues for the Grammaticalization and Distribution of Prominence-Conditioned Patterns in Adnominal Marking and Clitic Systems}

Bossong $(1991,155)$ proposes that DOM affected the emergence of leismo by analogy. If this holds, we should expect that DOM will have grammaticalized earlier. Since DOM and PA may be considered conceptually similar and negatively related in their distribution, it is possible that a similar precedence relation characterizes PA and adverbial clitics.

However, a different hypothesis emerges from Haspelmath's (2004) study of cross-linguistic variation in the morphology of certain object sequences across languages (e.g., Italian *lelo 'it to him/her' > glielo). ${ }^{13}$ Haspelmath makes two main arguments: that such variation is also determined in part by referential properties of arguments (i.e., similarly to prominence-conditioned PA and DOM) and that it is found in bound forms (clitics from a Romance perspective) earlier and more frequently than in free (pro)nouns (adnominal marking in the current paper). ${ }^{14}$ But why should changes in clitics precede the grammaticalization of similar structures in adnominal markers? Haspelmath's account relies on frequency effects in grammaticalization and the "more grammaticalized status" of clitics to begin with. This seemingly circular argument can be broken down as follows. The high frequency of a class of bound pronouns favors the earlier grammaticalization of such morpho-syntactic variation in bound pronouns relative to free pronouns and an open class of common nouns, most members of which are relatively infrequent. Since the relative token frequency of individual closed class clitics is higher than that of individual members in the open class of common nouns and since their collocation patterns in recurrent syntactic positions are more frequent (cf. Diessel and Hilpert 2016), they are likely to grammaticalize earlier.

If the diachronic Romance data on prominence-conditioned structures follow Haspelmath's proposal, we should expect to find that clitics grammaticalize the relevant patterns before adnominal markers do.

13 For a review of such clitic clusters in Romance, see Pescarini (2005).

14 Arguments are considered "free" if they may be used contrastively and occur alone as a complete utterance, see Haspelmath (2013). 
In this paper, I report the results of two studies that aim to answer two main questions:

i. What is the synchronic distribution of PA and bare nouns in Romance languages?

ii. How and when did PA and bare nouns and similarly motivated structures emerge in Spanish and French?

In addressing the distributional question, I conduct a comparative study based on a representative sample of languages from all phylogenetic sub-branches of the Romance family with the aim of extending the empirical panorama of previous broad observations regarding PA. In view of the conceptual and distributional relation between PA and other adnominal and clitic structures (DOM and DOI) (Section 2), I test their co-occurrence patterns. More specifically, I intend to consider whether PA may co-occur with incipient DOM or established DOM (Section 2.2.1) to achieve a higher resolution in this synchronic study relative to previous studies (Körner 1981; Bossong 2008). Additionally, I include clitics involved in prominence-conditioned indexing (DOI) to assess whether individual languages show a single tendency in prominence-conditioned structures across both systems of adnominal marking (PA/DOM) and cliticization or not.

The purpose of the diachronic study is to examine the grammaticalization of prominence-conditioned patterns in adnominal marking and cliticization in Medieval Spanish and French. I choose to focus on these languages as they are known to present different tendencies in prominence-conditioned patterns, the former showing Dом and leísmo, the latter-PA and adverbial clitics (partitive, locative).

In studying their grammaticalization, I use two measures. I use data on variation in relative frequency of clitics per century as an indication of their part in ongoing grammaticalization processes (cf. Enrique-Arias and Bouzouita 2013; Haspelmath 2004). This is similar to the use that Enrique-Arias and Bouzouita (2013), among others, make of diachronic frequency data as a reflection of grammaticalization. The process of semantic bleaching in grammaticalization (Section 2.1) - that is, the shift from referential, idiosyncratic meanings to more abstract grammatical meaning - often results in concomitant relaxation of restriction on usage contexts and higher frequency of linguistic expressions involved in grammaticalization. ${ }^{15}$ Additionally, I use an exploratory cor-

15 It is possible to cast doubt on the accuracy of the term "bleach" as indicative of some sort 
pus study aimed to assess the date of grammaticalization based on the earliest occurrence of the investigated structures between the 12th and the 16th centuries. This methodology is aimed to replicate previous results on the grammaticalization of PA and DOM (Sections 2.2.1-2.2.2) and add data on related clitics.

Why should this part of the study be qualitative? This is partly due to the fact that prominence-conditioned patterns are a low-frequency phenomenon (Haspelmath 2018; Section 2.2.1). For example, unambiguous cases of a PA comprise only about $3 \%(16 / 547)$ out of all post-verbal $d u$ and de la occurrences in the Base de Français Médieval corpus (BFM) (the alternative is not a PA but the preposition de juxtaposed with the singular definite article, see Italian example (3)). Similar figures emerge in the first 1,00o tokens out of 5,685 tokens of proclitic en in Medieval French. Consequently, corpora that are not tagged accurately or richly enough for the present purposes hinder any attempt to consider all and only relevant collocations.

Despite these limitations, using the frequency data as indicative of ongoing grammaticalization processes and the textual occurrence data in order to date the grammaticalization of PA and DOM, I aim to test whether the evidence supports the diachronic precedence of adnominal markers (Bossong 1991) or that of clitics (Haspelmath 2004; Section 4).

Finally, according to Haspelmath's (2004) prediction that clitics undergo grammaticalization earlier and more frequently than free adnominal morphemes (Section 2.2.3), only some of the logical possibilities of co-occurrence are predicted to occur across languages (Table 3.1).

One prediction is that such clitics may occur without similarly motivated adnominal markers (possibilities $(\mathrm{a}-\mathrm{c})$ ). Both adverbial and leismo cliticization are expected to co-occur (c) before the differentiation in prominenceconditioned tendencies to cliticizing either high or low-prominence referents. However, if the tendency to one type of prominence is entrenched in the clitic systems before its analogical transfer to the adnominal domain, we should expect for the PA to occur with incipient DOM, but not with established DOM (e, g).

Disregarding contact-induced changes, other logically possible co-occurrence patterns are hypothesized not to occur in the natural drift of grammaticalization (Table 3.2). Languages with a PA or DOM (incipient or established) but no prominence-conditioned cliticization (a-c) and languages that grammaticalize both PAs and an established Dом (irrespective of cliticization patterns) are excluded by hypothesis (d-f). So are also excluded languages

of semantic loss (cf. Sweetser 1988; Von Fintel 1995), but the resulting effects on frequency of collocations stands (Diessel and Hilpert 2016). 
TABLE 3.1 Predicted co-occurrence patterns of prominence-conditioned cliticization and nominal classifiers

Cliticization patterns

Partitive Locative leísmo Partitive Incipient Established article
DOM

$\begin{array}{ll}\text { (a) } & \checkmark \\ \text { (b) } & \\ \text { (c) } & \checkmark \\ \text { (d) } & \checkmark \\ \text { (e) } & \checkmark \\ \text { (f) } & \\ \text { (g) } & \end{array}$

TABLE 3.2 Hypothetically unpredicted cooccurrence patterns of prominence-conditioned cliticization and nominal classifiers

Cliticization patterns

Nominal classifiers

Partitive Locative leísmo Partitive Incipient Established article Dом Dом

(a)

(b)

(c)

(d)

(e)

(f)
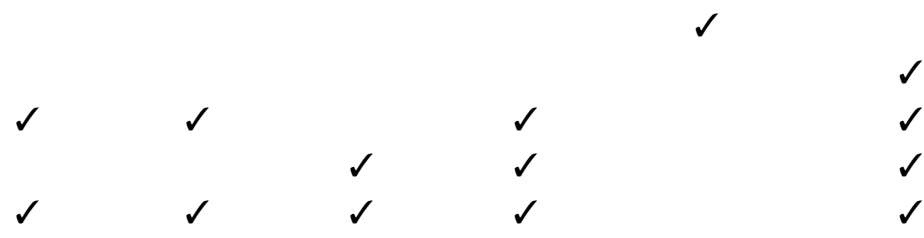

that grammaticalize PAS or DOM and retain both types of prominence-conditioned cliticization (f). Typological congruency in prominence-conditioned patterns follows from the expectation that grammaticalization of prominenceconditioned tendencies (to morphologically mark either prominent or nonprominent referents) in one subsystem will be transferred to the other (adnominal or clitic system) due, in part, to frequency effects on the process (Diessel and Hilpert 2016). 
TABLE 3.3 Genealogical coverage of European Romance varieties sample

\begin{tabular}{llll}
\hline & Eastern & Italo-Western & Southern \\
\hline Sampled varieties & 2 & $16^{\mathrm{a}}$ & 2 \\
Branch size & 4 & $3^{2}$ & 5 \\
Percentage sampled $^{\mathrm{b}}$ & $50 \%$ & $50 \%$ & $40 \%$ \\
\hline
\end{tabular}

a 16 in terms of Ethnologue's language records. However, my sample of the Italo-Western branch counts 18 varieties with the inclusion of non-standard varieties, which Ethnologue subsumes under their respective language-groups, namely Gascon (Occitan), Valencian (Catalan) and Vallader (Raeto-Romance, Switzerland).

b Concerning the percentage of sampled varieties, data for Southern Romance (Sardinian and Corsican) is problematic: while Sardinian dialects are represented by 4 language entries, Corsican dialects receive only 1 language entry in Ethnologue, which disregards its recognized sub-classification. Two major dialect groups are identified in Corsican: Cismonticu, influenced by Tuscan and Pumonticu, influenced by southern Italian and Sicilian varieties.

Synchronic Study: The Distribution of Prominence-Conditioned Patterns

In a representative sample of 22 languages from all sub-branches of Romance (Section 4.1), based on secondary sources (grammars and published papers), I tested each language for the occurrence of PA, DOM and clitics associated with prominence-conditioned patterns (leísmo, partitive, locative).

\subsection{Methods}

The genealogically representative sample of 22 languages (but 23 varieties, see Appendix 2) from all sub-branches of Romance is based on the genealogical classification of European Romance languages in the Ethnologue database of world languages (Lewis, Simons and Fennig 2015). For this convenience sample, I sampled two languages from each sub-branch: standard and non-standard or national and regional pairs, based on the assumption that such pairs may differ morpho-syntactically due to the bias of language planning in standard varieties (Auer 2004). The distribution of varieties is captured in Table 3.3.

The synchronic typology is based on grammars-mostly from the past two decades - and completed with data from published papers and available corpora (Appendix 2), with which I coded each variety for the occurrence of adnominal morphemes (PA, DOM), previously associated with prominenceconditioned marking as grosso modo nominal classification devices (Section 2) and clitics that associate with similar functions (leismo, partitive and locative clitics). 


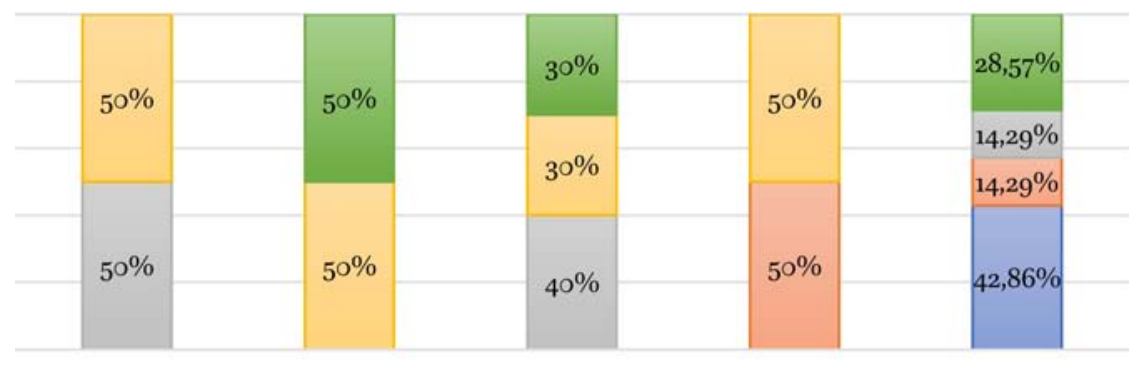

Southern

Eastern

Ibero-Romance Italo-Dalmatian Gallo-Romance

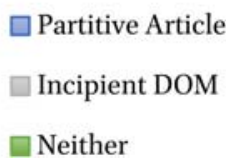

\section{$\square$ Partitive/Incipient DOM \\ $\square$ Established DOM \\ m Partitive/Established DOM}

FIGURE 3.3 Co-distribution of "partitive article" and Differential Object Marking per genealogical subgroup in European Romance

By identifying their co-occurrence patterns in European Romance languages, I aim to test the predictions that follow from the hypothesized precedence of clitics over adnominal marking of free (pro)nouns in grammaticalization (Haspelmath 2004; Section 3).

\subsection{Results}

Most generally, $60.86 \%(14 / 23)$ of the sample total show incipient or established DOM (Section 2.2.1) as opposed to $21.74 \%(5 / 23)$ that show PAs (Appen$\operatorname{dix} 1)$.

In terms of areal distribution, PAs generally occur in the northern Romance area, while DOM occurs in the southern Romance area. However, PAs and incipient Dом со-occur in some northern varieties of the Gallo-Romance and ItaloDalmatian branches (Appendix 2). Strikingly, none of the sampled languages features both PA and established DOM (Table 3.4).

The co-distribution of PAs and DOM with adverbial clitics (partitive and locative) is not uniform across varieties (Figure 3.4).

All PA-languages show both adverbial clitics. However, only 50\% of languages with bare nouns ( $=$ no PA) and DOM show such clitics. $80 \%$ of languages with neither PA nor DOM lack these clitics (one such language shows the partitive clitic only).

Grouping all varieties according to these co-occurrence patterns (Table 3.5), PAs always occur with both clitics, whereas incipient DOM and neither adnominal marker vary in this respect. ${ }^{16}$

16 Ladin (Raeto-Romance, Switzerland) is the one variety in the sample with only the parti- 


\section{Differential Object Marking}

\begin{tabular}{lccc} 
Partitive article & None & Incipient & Established \\
\hline Extant & $5^{\mathrm{a}}$ & $1^{\mathrm{b}}$ & 0 \\
Inexistant & $5^{\mathrm{c}}$ & $7^{\mathrm{d}}$ & $5^{\mathrm{e}}$ \\
\hline
\end{tabular}

a Emilian, Ligurian, French, Italian, Arpitan (another term for Francoprovençal used elsewhere in the volume).

b Italian (northern varieties).

c Asturian(Eastern), Extremaduran, Provencal, Istro-Romanian, Ladin.

d Portuguese, Galician, Aragonese, Vallader, Asturian (Western), Gascon, Corsican.

e Spanish, Catalan (Central, Valencian), Daco-Romanian, Sicilian.

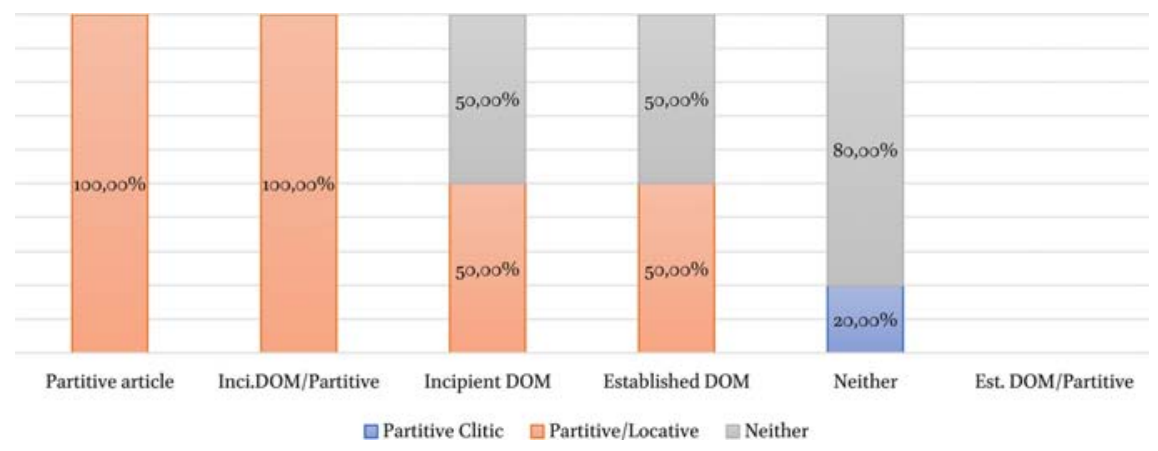

FIGURE 3.4 Co-distribution of nominal classification strategies and partitive/locative clitics

\subsection{Discussion}

This comparative overview precludes the strong hypothesis of mutual exclusion between PA and Dом (pace Körner 1981), which do co-occur in individual languages to some extent. Although none of the sampled languages features both full-fledged PA and established DOM, some languages feature PA and incipient ром (e.g., some northern Italian varieties) or established Dом with a

tive clitic. At face value, this appears to suggest an implicational relation: if a language has locative clitics, it also has a partitive clitic (but not vice-versa). However, this is possibly a contact-induced pattern due to borrowing of the partitive clitic from northern Italian varieties (Stark 2015). Therefore, it does not affect the validity of previous generalizations about the non-implicational relation between locative and partitive clitics (Benincà and Poletto 2005). 
TABLE 3.5 Co-occurrence patterns of adnominal classification patterns and adverbial clitics

Partitive article Part./Inc. Dом Inc. Dом Est. Dом Neither

\section{Both}

Partitive only

Neither

limited use of PA, such as Corsican, an established Dom language (Neuburger and Stark 2014), in which the PA is limited to a number of recurrent idiosyncratic expressions (Franchi 2000; Section 3.1), possibly due to long-term contact with northern Romance (e.g., French). This is suggestive of a weaker version of Körner's hypothesis, namely, that there is a negative relation between PA and DOM. The negative relation and typological gap (i.e., PA/established DOM) align with previous observations that languages with PA and DOM tend to differ in certain syntactic properties which arguably favor the emergence of PA in northern Romance (e.g., word order variation and the retention of morphological reflexes of neuter gender, see Carlier and Lamiroy 2014; Stark 2005).

The gap of a language with both full-fledged PA and established DOM could be accidental in principle. However, it accords with the predictions proposed at the outset (Section 3). Specifically, I hypothesized that as one type of prominence-conditioned adnominal marking becomes obligatory with a greater range of referents, so the grammaticalization of its counterpart in the same language is expected to become less likely. For instance, in the natural drift of grammaticalization, DOM is expected to remain incipient in PA languages.

Some languages show only leísmo or adverbial clitics, but neither PA nor Dом. For instance, eastern Asturian (Ibero-Romance) shows leísmo without DOM and Provençal Occitan (Gallo-Romance) shows partitive cliticization without PA. In this they differ from their genealogically-related neighbours: western Asturian features both leísmo and incipient Dom and northern and central varieties of Occitan also show PA. ${ }^{17}$ The hypothesized precedence of clitics in grammaticalization predicts that prominence-conditioned adnominal markers imply the occurrence of such clitics (Section 3). However, one of the sampled languages, Vallader (Raeto-Romance, Switzerland), counters this expectation with its Dом but seemingly no dedicated prominence-conditioned clitics.

17 In north-central Occitan PA may show full-fledged article morphology, but more frequently it surfaces as invariable de (Bossong 2008). 
Another prediction was for languages with both prominence-conditioned adnominal phrases and clitics to be typologically consistent in marking and cliticizing referents of similar prominence (either high or low). Disregarding contact-induced changes, this expectation follows from the precedence of clitics hypothesis (Section 3). While it holds in most cases as a tendency, it fails as a universal generalization since some DOM languages of southern Romance (e.g., Sicilian, Sardinian) feature adverbial clitics. This fact also means that the occurrence of DOM does not imply the non-occurrence of adverbials nor does it imply the occurrence of leismo. However, one such implication holds: if a language has a PA, then it also has adverbial clitics.

Setting aside language contact, this distribution is amenable to two kinds of diachronic accounts. Following Bossong's $(1991,155)$ precedence of Dом proposal, if extended to PA, then DOM and PA would have emerged before functionally similar clitics, but such adnominal markers would also be first to be lost. Alternately, the relevant cliticization patterns grammaticalize earlier (following Haspelmath 2004). In that case, the lack of similar adnominal markers results not from their posterior loss, but from their non-grammaticalization in the first place.

Section 5.2 presents the diachronic study in Spanish and French, two languages with typologically consistent adnominal and clitic patterns that represent opposite poles of prominence on the continuum. This may shed light on the precedence of either clitics or adnominal markers in two "well-behaved" languages. Prominence-Conditioned Patterns

The synchronic study (Section 4) focused on the co-occurrence patterns of several prominence-conditioned adnominal markers and related clitics. In the following diachronic study, I aim to describe central topics in their grammaticalization in Spanish and French as representatives of two poles of typologically inverse prominence-conditioned patterns.

This study concerns Medieval Spanish and French (12th-16th centuries) using two measures. First, I observed the relative frequency of third person pronouns - the diachronic source of the Romance clitics-which I later set against the dating of grammaticalization of the PA and DOM (Section 2). ${ }^{18}$

18 Since the pronouns are not yet cliticized and bound to the verb in a fixed position during this period (Fontana 1993), I refer to them as pronouns rather than clitics. 
Additionally, I tried to replicate this dating using corpora queries in order to find examples from the first century of occurrence of each prominenceconditioned pattern.

\subsection{Methods}

For the quantitative measure of the relative frequency of third person pronouns, I used data from the OLDES corpus of Old Spanish $(\mathrm{N}=22,063,434)$ (Sánchez-Marco, Bofias, Bassaganyas, Chandía and Fontana, n.d.; henceforth oldes) and the Base de Français Médiéval corpus of Medieval French $(\mathrm{N}=3,550,000)$ (Cédille 2016; henceforth BFM).

In this part of the study, the investigated pronouns are the dative and adverbials (partitive and locative) (Section 2.2.2) in addition to accusative and the reflexive-syncretic pronouns (e.g., French $l e$ and $s e) \cdot{ }^{19}$ To allow for comparison of relative frequency within language per century and across both languages, frequency data on third person pronouns were normalized for the number of tokens per 1 million words in each century.

In the "qualitative" textual occurrence data, I used a review of examples from 50o-year corpora (12th-16th centuries) in order to try and replicate previous proposals regarding the date of grammaticalization of $\mathrm{PA}$ (Section 2.1) and DOM $(2.2 .1) \cdot{ }^{20}$

\subsection{Results}

Section 5.2.1 presents the ratio of reach third person pronoun out of all third person pronoun tokens per 1 million words per century in Medieval Spanish (Figure 3.5) and Medieval French (Figure 3.6). Section 5.2.2 reviews the emergence of prominence-conditioned patterns based on a series of examples.

\subsubsection{Variation in Relative Frequency of Third Person Pronouns}

Beginning with adverbial pronouns, both locative and partitive are infrequent in Spanish (less than $5 \%$ of all pronouns throughout the period) and disappear by the end of the 16th, whereas in French, they are relatively frequent. In fact, between the 14th and the 15th centuries the French locative gains the most in relative frequency at the expense of the dative. This change contrasts with

19 Although the accusative and reflexive bound pronouns are not reviewed in the prominence-conditioned patterns (Section 4), they are included to allow for a comprehensive view of the changes, which reveals yet another difference between Spanish and French in this period.

20 For quantitative measures in the grammaticalization of Dom and "partitive article", see Carlier and Lamiroy (2014); Cuétara Priede and Company Company (2014). 


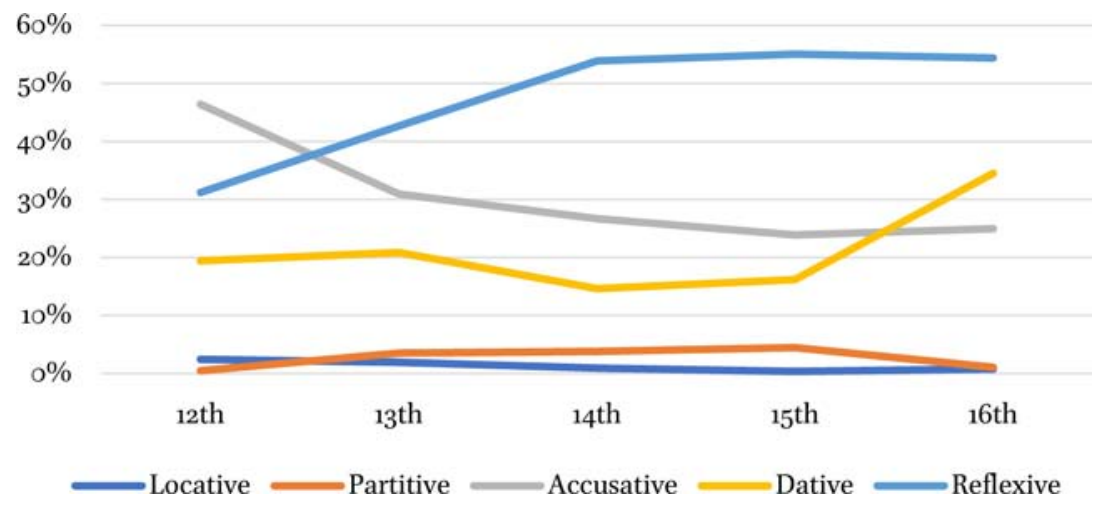

FIGURE 3.5 Relative frequency of third person pronouns per century in Medieval Spanish (OLDES)

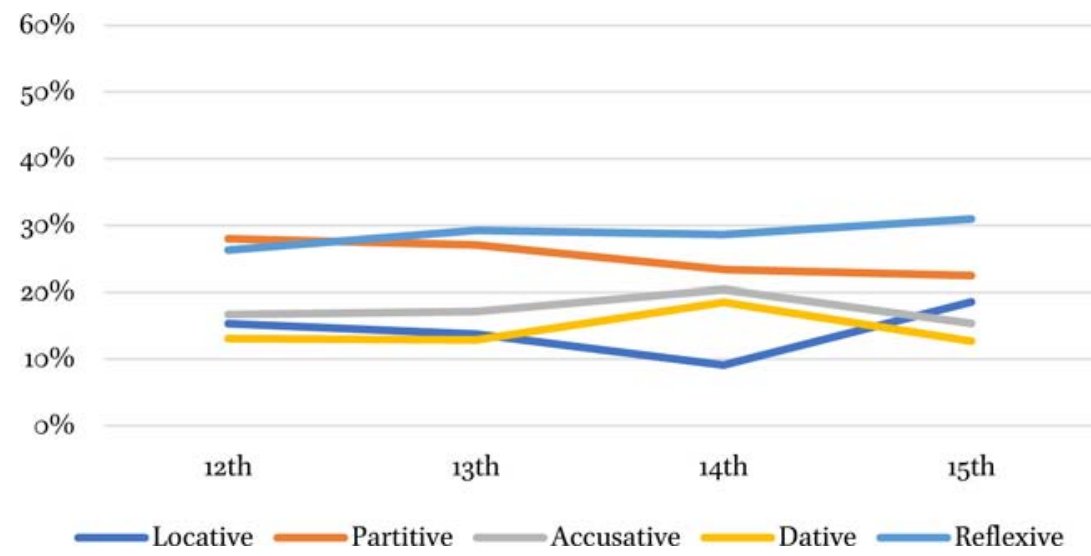

FIGURE 3.6 Relative frequency of third person pronouns per century in Medieval French (BFM 2014)

a sharp increases in the relative frequency of the Old Spanish dative between the 15 th and the 16 th centuries.

Finally, while the reflexive-syncretic se increases in Spanish and stabilizes at about $55 \%$, its Medieval French counterpart remains rather stable at about $30 \%$. Its frequency in French relative to the other clitics increases only slightly between the 14th and the 15th centuries (an increase of less than $3 \%$ ), while the dative and accusative pronouns decrease in frequency. The Spanish third person accusative between the 15th and the 16th centuries sees a previously constant decrease in relative frequency coming to a halt. When this change occurs, Spanish partitive decreases in frequency before its demise in the 16th century. 
5.2.2 Qualitative Morphosyntactic Data

This section covers representative examples of the major prominence-conditioned patterns (Section 3) in order to evaluate the chronology of their emergence and grammaticalization in Medieval Spanish and French.

Prominence-conditioned pronominalization is incipiently attested in both languages at an early stage. The 13th century Spanish corpus attests to the occurrence of the partitive pronoun in a genuine partitive meaning (11a) and leísmo (11b).

(11) Old Spanish

a. et si oro o argento quisiera meter en apreciadura... and if gold or silver wish.IMPF.3SG put.INF in evaluation tomen ende la diezma parte take.PRS.3SG of.it the tenth part 'and if you wished to evaluate gold or silver, they would take one tenth of it.' (Corpus Diacrónico del Español, anonymous, 1242-1275, Española 2O16b; henceforth CORDE)

b. El fijo es fecho dela semiente del padre por the son be.PRS.3SG make.PTCP of.the sperm of.the father for eso le=ama de tan grande amor su padre

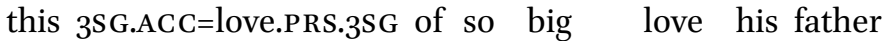
'The son is made of the sperm of the father. For this, the father loves him so.' (1293, CORDE 2016)

In (11a) the pronoun ende corefers with the indefinite, substance-denoting oro $o$ argento ('gold or silver') and marks genuine partition of a given quantity of material. In (11b) from the same period, the dative-syncretic accusative le is coreferential with el fijo ('the son'), a definite, kinship-denoting noun.

Adnominal markers pattern similarly. Both incipient DOM and an incipient form of partitive determination are documented in Old Spanish. DOM in early Old Spanish (13th-14th centuries) applies to human-denoting personal pronouns (12a), proper names (12b) and kinship terms (12c).

(12) Old Spanish

a. Conosco a vos

know.PRS.3SG DOM 2PL(.HON)

'I know you.' (1321; CORDE 2O16) 
b. Tu amas a Leucotoe sola 2SG.SBJ love.PRS.3SG DOM Leucotoe only 'You love Leucote only.' (Alfonso X 1275; CORDE 2016)

c. Yo vos amo verdaderamenete como padre 1SG.SBJ 2PL.OBJ love.PRS.1SG truly as father ama a sus hijos love.PRS.3SG DOM 3PL.POSS sons 'I love you truly like a father loves his sons.' (1300-1305; CORDE 2016)

An incipient form of partitive determination is also attested in Old Spanish with substance-denoting direct objects varying between unmarked and partitive phrases (13).

(13) Old Spanish

non deue mandar el jugador que

NEG need.PRS.3SG ask.INF the judge COMP $g e=l a=d e n \quad d \cdot e l$ pan $o$ d.el vino 3SG.DAT=3SG.ACC=give.PRS.SBJV.3PL of-the bread or of-the wine 'The judge need not ask that they give him/her bread or wine.' (13th century, OLDES)

The results of the diachronic study in Spanish are summarized below (Table 3.6). ${ }^{21}$

In Old French, similarly to Old Spanish, the clitic en (cognate with Old Spanish ende) occurs in ablative uses (i.e., referring to spatial sources, e.g., Old French $s^{\prime}=e n_{i}=i s s e n t$, 'went out of there') (14a) and in reference to quantitative expressions, such as to parts of a group of distinct entities. (e.g., Old French dis mile en $=o t$, 'ten thousand of them he had') (14b) (note that (14b) is a continuation of (14a)).

(14) Old French

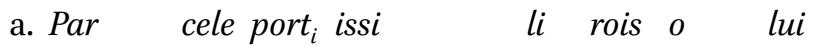
through this door exit.PST.3SG the king APUD 3 SG $s^{\prime}=e_{i}=$ issent mil borjois $_{k}$ $3(\mathrm{PL} . \mathrm{REFL})=\mathrm{ABL}=$ exit.PST.3PL thousand citizens

21 See Gerards and Stark, this volume, for an analysis of nominal phrases with a "partitive article" in (Old) Spanish as bare partitives, that is, Quantifier Phrases with zero $\mathrm{Q}^{\circ}$. 
TABLE 3.6 Clitic and (pro)nominal prominence-conditioned patterns in Medieval Spanish

Period

Cliticization

Free (pro)nominal marking

\section{Low High Incipient Established Partitive DOM DOM article}

$\begin{array}{lllllc}\text { 12th-13th centuries } & \checkmark & \checkmark & \checkmark & - & (\checkmark) \\ \text { 14th-15th centuries } & \checkmark & \checkmark & \checkmark & - & (\checkmark)^{\text {a }} \\ \text { 16th century } & - & \checkmark & - & \checkmark & -\end{array}$

a A stage 1 partitive pattern (cf. Carlier and Lamiroy 2014) alternates with bare nouns (cf. Section 2.4.4).

'The king went out through this door. A thousand citizens around him went out of there ...' (APUD=apudlocative) ${ }^{22}$ (Thebes2, p. 65 v. 8136 , 13th century Cédille 2016; henceforth BFM)

b. Et quant il fu hors en la plaigne dis and when 3M.SG.SBJ be.PST.3SG out in the plain ten Mile en=ot en sa compaigne thousand of.it=have.PRS.3SG in 3SG.POSs company '... and when he was out in the plain, ten thousand of them accompanied him.' (Thebes2, p. 65 v. 8136, 13th century, BFM)

Additionally, Old French en in the 13th century may carry genuine partitive meanings, referring to a part of determinate quantities of substance. In example (15), en corefers with dou mortel fruit ('of the deadly fruit') as the direct object of menjar ('to eat') and the 'give'-verb donner. However, the direct object of cueillir ('to gather') is accusative-cliticized (discussed in Section 5.3).

(15) Old French

Il li=fist son desloial talent mener

3M.SG.SBJ 3SG.DAT=make.PST.3SG 3SG.POss disloyal desire lead.INF a ce que ele cueilli $\quad[\text { dou mortel fruit }]_{i} d e$ ALL this COMP 3F.SG.SBJ gather.PST.3SG from. the deadly fruit of

22 Apudlocative: marking the spatial relations of proximity (e.g., English 'nearby') or more specifically 'at the (habitual) sphere of' (e.g., French chez). 


$$
\begin{aligned}
& l '=\text { arbre }[\ldots] \text { quant ele l'=ot cueilli si } \\
& \text { the =tree when } 3 \text { F.SG.SBJ } 3 \text { SG.ACC=have.PRS.3SG gather.PTCP so } \\
& \text { en } n_{i}=\text { enenja en } n_{i}=\text { dona mengier } a \text { Adam } \\
& \text { of.it=eat.PST.3SG and of.it=give.PST.3SG ALL eat.INF DAT Adam }
\end{aligned}
$$

'He made her lead her disloyal desire to the point that she gathered some of the deadly fruit of the tree ... When she gathered it, so she ate some and gave some to Adam.' (Qgraal_cm, p. 186d, BFM, 1225-1230)

As early as the 11th century Old French, preverbal adverbial en/an occurs collocated with the consumption verbs such as mangier ('eat') (16a-b) with the resulting parti-generic interpretation, such as referring to some part of the classes of wolf, pork, dog (16b) or to an indeterminate quantity of an indeterminate non-singular, human-denoting whole (e.g., 'hostages') (16c).

(16) Old French

a. et li=apareilla char et poisson, mes and 3SG.DAT=prepared the=person meat and fish but il n'=en menja oncques

3M.SG.SBJ NEG=PART eat.PST.3SG at.all

'And they prepared meat and fish for him, but he did not eat any of it.' (qgtaal_cm, p. 203d, 13th century, BFM)

b. $N^{\prime}=e n$ mangerunt ne lu ne porc ne chen. NEG=PART eat.FUT.3PL NEG wolf NEG pork NEG dog 'They would not eat neither wolf nor pork nor dog.' (roland, 138, v. 1751, 11th century, B FM)

c. S'il voelt ostages, il en avrat if=3M.SG.SBJ want.PRS.3SG hostages 3M.SG.SBJ PART have.FUT.3SG par veir

by truth

'I he wants hostages, he will have (some) indeed.' (roland, 30, v. 87, 11th century, BFM)

Is this the only prominence-conditioned cliticization in Old French? No. The Old French locative clitic $i$ may cliticize referentially non-prominent indirect objects, such as institutions composed of groups of humans (e.g., monasteries in (17a)). Unlike the locative, the Old French dative li cliticizes prominent referents, such as human-denoting singular third person $(17 \mathrm{~b})$. 
(17) Old French

a. Il avint qu'=ele fonda et

it happen.PST.3SG COMP=3SG.F found.PST.3SG and

estora [une abeie de nonnains] et

establish.PST.3SG an abbey of nuns and

$i=$ donna assés viles bones et riches

DAT(.LOC)=give.PST.3SG much estates good and rich

'It happened that she established an abbey of sisters and gave it/them many a good and rich estates.' (SBath1, 31, 1250-1300, B FM)

b. Après li cuens Loeis demanda un autre roiaume et afterwards the king Lewis ask.PST.3SG a other kingdom and on li=donna

they 3 SG.DAT=give.PST.3SG

'Afterwards, King Lewis asked for another kingdom and they gave him.' (clari, p. 105, 1300, BFM)

In the domain of adnominal marking, consider the collocation of the consumption verb boire ('drink') and its direct object vin ('wine'). While the direct object may remain morphologically unmarked in early Middle French (boire vin ver-

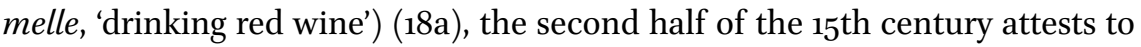
its marking by the juxtaposition of $d e$ and the definite determiner (boire del vin claret, 'drink some clary wine') (18b).

(18) Middle French

a. c'est signe de boire vin vermelle

DEM=be.PRS.3SG sign of drink.INF wine red

'It's a sign of drinking red wine.' (quenouilles2, p. 91, 1396, вFM)

b. apportez a nous un foitz a boire $d u$ vin bring.IMP.2PL DAT 1PL a time ALL drink.INF PA.M.SG wine claret

clary

'Bring us, one time, some clary wine to drink.' (Maniere 1396, 12, ca. 1480, BFM)

Note that only example (18b), in which the PA occurs, is in the imperative (i.e., a non-indicative) clause. In a similar vein, the abstract-denoting pacience ('patience') remains unmarked in indicative clauses (19a), but it is marked with the preposition de under negation (19b) (the latter, though not a case of PA, may prove relevant, see Section 5·3). 
(19) Middle French

a. En tous leurs affaires et necessitez et adversitez in all 3 PL.Poss affairs and needs and difficulties doivent avoir pacience must.PRS.3PL have.INF patience 'In all their doing, needs and difficulties, they must have patience.' (jouvencel2, 79, 15th century, BFM)

b. Finablement ne peüt le roy avoir de pacience finally NEG can.PRS.3SG the king have.INF of patience 'Finally, the king could not have patience.' (commyn2, 122, 15th century, BFM)

Example (20) from the 13th century shows what appears to be a PA in the absence of any phorically mentioned definite referent for $d u$ vin ('wine').

(20) Old French

Cascun nuit, quant il se=choucheroit, every night when 3M.SG.SBJ 3(SG.REFL.)=go.to.bed.IMPF.3SG $q u^{\prime}=$ ele le $=$ servist $\quad d u \quad$ vin COMP=3F.SG.SBJ 3M.SG.ACC=serve.PST.3SG PA.M.SG wine 'Every night, when he went to sleep, she served him some wine.' (SBath1, $2,13^{\text {th }}$ century, $13^{\text {th }}$ century, B FM)

Finally, to consider the possible co-occurrence of partitive patterns and incipient Dом in Medieval French, similarly to those observed in Old Spanish (cf. examples (18)-(19)), I searched the BFM corpus for DoM patterns, but found none.

The results of the diachronic study in French are summarized below (Table $3.7)$.

\subsection{Discussion}

Based on findings of the diachronic study, the clitic systems of Medieval Spanish and French grammaticalized prominence-conditioned patterns in the 11th14th century before the full-fledged grammaticalization of PAs in French and DOM in Spanish down opposite poles of prominence (14th-16th centuries).

While leismo occurs as early as $13^{\text {th }}$ century Spanish alongside incipient Dом (in line with Eberenz 2008), established Doм grammaticalized only in the 16th century (in line with Cuétara Priede and Company Company 2014; Von Heusinger and Kaiser 2005). Similarly, Old French (11th-13th centuries) already 
TABLE 3.7 Clitic and (pro)nominal prominence-conditioned patterns in Medieval French

Period Cliticization Free (pro)nominal marking

$\begin{array}{cccc}\text { Low High } & \begin{array}{c}\text { Incipient } \\ \text { DOM }\end{array} & \begin{array}{c}\text { Established } \\ \text { ВFM }\end{array} & \begin{array}{c}\text { Partitive } \\ \text { article }\end{array}\end{array}$

12th-13th centuries 14 th -15 th centuries 16th century

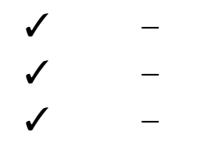

$\begin{array}{ccc}- & - & - \\ - & - & (\mathcal{J})^{\mathrm{a}} \\ - & - & \checkmark\end{array}$

a The 15th century sees the emergence of $a$ de-based plural indefinite article, but not a singular "partitive article" (cf. Carlier and Lamiroy 2014; Section 2.4.4).

features prominence-conditioned adverbial clitics, such as a partitive clitic in its parti-generic use with no PA, which only grammaticalized in Middle French (14th-17th centuries). While Old Spanish features a partitive pronoun ende, currently available examples only attest to a genuine partitive use.

Relating these findings to the relative frequency of third person pronouns, both languages show starkly different patterns. Concerning the dative clitics in both languages, the Spanish dative fluctuates somewhat before its major increase $(18 \%)$ in relative frequency between the 15 th and 16 th centuries, while the French dative decreases in frequency between the 14th and he 15th centuries concomitantly with a major increase in the relative frequency of the locative. Note that in both cases, it is a clitic associated with the same prominencetendency of an emergent adnominal marker in the language, Spanish Dом and French PA, that sees its relative frequency increase.

If we consider the adverbial pronouns, their relative frequency remains extremely low in Medieval Spanish before their eventual demise in the 16th century. In Medieval French both adverbial pronouns remain rather frequent throughout the whole period. In fact, its locative clitic increases in relative frequency the most between the 14th and the 15th centuries, that is, during the period in which the PA emerges.

Regarding the relation between the French partitive clitics and the emergence of the PA, we have seen that Old French en in the 13th century may carry genuine partitive meanings, referring to a part of determinate quantities of substance. This possibility appears similar to stage 2 in the grammaticalization of adnominal PAs (e.g., as described in Carlier and Lamiroy 2014) (Section 2.1) and predates it in its occurrence. This was illustrated in example (15), where en corefers with dou mortel fruit ('of the deadly fruit') as the direct object 
of menjar ('to eat') and the 'give'-verb donner. However, the direct object of cueillir ('to gather') remained accusative-cliticized. One way of explaining this difference is that it parallels the grammaticalization of the "partitive article" in the domain of free nominal marking, which emerges with consumption verbs whose objects denote parts of a determinate substance (cf. Carlier and Lamiroy 2014).

Against this analysis, one may argue the structure of example (15) is underlyingly a ce dou mortel fruit que ele cueilli ('that (part) of the deadly fruit which she took'). Given such a scrambling analysis, the accusative clitic to the verb cueillir refers to the head $c e$, which, in turn, heads a relative clause that is interpreted referentially as 'that part', a definite, identifiable entity. Then the referential property of 'that part' as an identifiable entity accounts for its accusative rather than partitive-cliticization. However, I propose a different solution that does not require to assume such scrambling, namely, that $c e$ heads a relative clause that denotes not an entity, but the predicated event of gathering some of the deadly fruit. In Old French, the expression mener a ce que may be interpreted as 'lead to (the event) that' or 'cause that'. With this analysis in mind, where ce does not refer to 'that part', the following accusative clitic corefers anaphorically with dou mortel fruit ('of the deadly fruit'). In fact, the same expression occurs later in the same text in reference to the same event. In example (21) ce cannot refer to that part which was gathered, but only to the event of gathering some (indeterminate quantity) of the deadly fruit.

(21) Old French

il fist son desloial talent mener a ce 3M.SG.SBJ do.PST.3SG 3SG.POss disloyal desire lead.INF ALL this $q u^{\prime}=i l \quad$ cuillir dou mortel COMP=3M.SG.SBJ 3SG.DAT=make.PST.3SG gather.INF of.the deadly fruit de l'arbre fruit of the=tree 'He led her disloyal desire lead to this, that he made her gather from the deadly fruit.' (Qgraal_cm p. 210b, BFM)

Note that only 8 out of 8,031 occurrences of preverbal adverbial en/an in the tagged BFM corpus involve the verb mangier ('eat') and only 10 tokens involve the verb boire ('drink'). Since adnominal PA appears to emerge in collocations with consumption verbs (e.g., 'eat', 'drink'), this rarity is of diachronic importance. It accords with the designation of partitive and Doм morphosyntax as low-frequency phenomena (Haspelmath 2018; Hawkins 2012; Seržant and Wizlack-Makarevich 2018). However, despite the rarity of such uses of en, 
they occur in Old French as early as the 11th century (16a), similarly to encliticization of indeterminate quantitative expressions (16c), centuries before the emergence of adnominal PA in French (Section 2.1). In both cases, the interpretation is parti-generic, referring to some part of the classes of wolf, pork, dog (16a) and hostages (16c).

With respect to the diachrony of adnominal markers, the findings largely accord with previous dating of their emergence. An incipient form of an adnominal partitive is attested in Old Spanish (e.g., with substance-denoting direct objects varying between bare and partitive phrases, $d e$-marked in juxtaposition to a definite article (13) and this simultaneously with the occurrence of incipient DOM (Eberenz 2008)). In French, however, DOM does not occur in any form during that period and the PA grammaticalizes only during the Middle French period (14th-17th centuries). This corroborates previous research indicating the absence of Dом in Medieval French (Fagard and Mardale 2014). Its absence in the Medieval French corpus aligns with the lack of dedicated high-prominence Differential Object Indexing (i.e., "Differential Cliticization"). However, two notes are in place regarding the grammaricalization of PA and DOM in Medieval French and its relation to areal distinctions between northern and southern varieties.

While Carlier and Lamiroy (2014) date the grammaticalization of the French PA, marking indeterminate substance-denoting nouns to the 16 th century, they note that such uses first occur in the 13th century. They designate such early tokens as "exploratory expressions" (Harris and Campbell 1995, 72) that vary with similar structures where they do not occur. Only once grammaticalized, are they analyzed as heralding the forthcoming grammatical change. This can be illustrated with a 13th century example from the BFM corpus (22) in which an apparent case of PA marks the direct object $d u$ vin ('wine'), which appears to lack any phorically mentioned referent that would make it definite.

(22) Old French

Cascun nuit, quant il se=choucheroit, every night when 3M.SG.SBJ 3(SG.REFL)=go.to.bed.IMPF.3SG $q u^{\prime}=$ ele le $=$ servist $\quad d u \quad$ vin COMP=3F.SG.SBJ 3M.SG.ACC=serve.PST.3SG PA.M.SG wine 'Every night, when he went to sleep, she served him some wine.' (SBathi, $2,13^{\text {th }}$ century, $13^{\text {th }}$ century, BFM)

This apparent counterexample to the 16th century dating can be explained out as an exploratory expression. However, its occurrence in a 13th century text of Picard origin (northern France) is expected to the extent that PA is known to 
occur in northern Romance varieties (Section 2.1 and Section 4). While it may very well be an exploratory expression, only quantitative analysis will allow us to evaluate its frequency at the regional level and follow its dialectal spread.

In testing the extension of PA to indefinite, substance-denoting and abstract nouns, two examples revealed a possible difference between indicative and non-indicative clauses (18)-(19); the latter may have seen the PA emerge earlier. Although de-marked direct objects under negation do not illustrate PA in the narrow sense, it may prove fruitful to consider the relation between the two. ${ }^{23}$ For instance, Tuten et al. (2016) argue that indefinite, mass-denoting and plural-denoting nouns in Aragonese (Ibero-Romance) occur with a PA, but they illustrate this with a de-phrase under the scope of negation (23).

(23) Aragonese

¿ya no ne=b'ha de lupos?

already NEG NE=LOC=have.PRS.3SG of wolves

'Are there no wolves anymore?' (Nagore Lain 1986, 111)

The effects of negation on the use of determiners across languages (Miestamo 2014) may also come into play in the grammaticalization pathway of the PA in the form of earlier marking under negation than in indicative clauses (17)-(18).

To consider whether Medieval French featured Dом in this period, let us consider apparent contradictions to its purported lack. When a perception verb like veoir ('to see') takes an infinitive clause complement, the latter is sometimes found marked with the preposition $a$ (Fagard and Mardale 2014). The verb veoir takes a ma mere plorer ('my mother cry') as a complement clause in example (24). ${ }^{24}$

(24) Old French

Je voi a ma mere plorer

1SG.SBJ see.PRS.1SG ALL my mother cry.INF

'I see my mother cry.' (Bourciez 1946, 374, cited in: Fagard and Mardale 2014)

23 Dobrovie-Sorin, this volume, discusses such negative contexts in comparison with bare nouns.

24 Fagard and Mardale (2014) do note the occurrence of Doм in 16th French authors of Gascon origin. However, this is amenable to a contact explanation in line with an incipient DOM pattern in Gascon Occitan. 
Regardless of whether this is analyzed as DoM which applies to whole complement clauses (a ma mere plorer) or as case of Differential Subject Marking ( $a$ ma mere), in which the subject of an infinitive complement clause is $a$-marked as if it were the object of the matrix clause in accusative-cum-infinitive clauses, Old French does not feature traditional Doм. Moreover, my review of the BFM corpus shows that such exceptional marking of complement clauses is far from obligatory even within specific noun classes. For instance, while kinship terms are among the first classes to be marked in traditional DOM (Section 2.2.1), not all kinship terms are $a$-marked in embedded subject position in Medieval French. Compare the marked 'my mother' in (24) and the unmarked 'my dear son' in (25) where the complement clause is mon chier fil devant mes iex mourir ('my dear son die in front of my eyes').

(25) Old French

Je voi mon chier fil devant mes iex mourir

1SG.SBJ see.PRS.1SG 1SG.POSS dear son before 1SG.POss eyes die.INF 'I see my dear son die in front of my eyes.' (passpal, 47, v. 1212, early 14th century, BFM 2016)

To summarize, patterns akin to full-fledged PA and DOM rarely if ever occur in Medieval Spanish and French, respectively. However, their DOI counterparts, leísmo in Spanish and adverbial clitics in French, occur early in the history of both languages. Both languages grammaticalize their respective adnominal markers by the 16th century. Concomitantly with the emergence of established Dом (13th-16th centuries) (Cuétara Priede and Company Company 2014; Von Heusinger and Kaiser 2005), Spanish sees its seldom used partitive de-phrases marking — substance-denoting direct objects (Eberenz 2008) - fall out of use by the 17 th century (Harris-Northall 2005). This process of demise and emergence in the system of adnominal markers in Spanish is simultaneous with similar effects in the pronoun system with the decrease in adverbial pronouns to the point of oblivion and the increase in dative between the 15th and 16th century. In French, the partitive and locative clitics remain rather frequent and the frequency of the locative increases by the 16th century (as that of the dative decreases). Although this study cannot tell how much of these changes is due to prominence-conditioned clitic patterns, it is possible to note a general trend: changes in the relative frequency of pronouns take starkly different forms from the early outset of Medieval Spanish and French. This trend continues at least until 16th century Spanish and French grammaticalize DOM and PA, respectively (i.e., adnominal markers that align with their early tendency in prominence-conditioned clitics). 
Towards a Comprehensive Account: Prominence-Conditioned Morpho-syntax and the Romance Bare/Partitive Distinction

This study produced several descriptive generalizations concerning the system of prominence-conditioned classification in Romance:

1. Full-fledged PA precludes established Dом.

2. Prominence-conditioned clitics grammaticalized before PA and Dом in Spanish and French.

3. Medieval Spanish and French differ in their diachronic variation in the relative frequency of clitics.

The apparent synchronic gap of no language with both established DOM and a full-fledged PA means that no language makes both PA and DOM obligatory to the full range of potentially-marked noun phrases. This negative relation between DOM and PA is reflected diachronically in the case study of Spanish and French. As Spanish shifts from an incipient to an established Dом system (13th-16th centuries), its partitive morphemes, the pronoun ende and partitivemarking de-phrases decrease and fall out of use. In Medieval French, on the other hand, neither Dом nor leísmo-type clitics are found, and the PA grammaticalizes in the same period of time (14th-16th centuries). This negative relation between PA and DOM might be related to other trends in the broader system of prominence-conditioned adnominal marking and cliticization.

In the case study of Medieval Spanish and French, prominence-conditioned clitic patterns grammaticalized before their adnominal counterparts. This aligns with the Haspelmath's (2004) proposal that certain grammaticalization processes occur in clitics (among other bound forms) earlier and more frequently than in free (pro)nouns since the difference in relative token frequency of individual members in a closed class (e.g., of clitics) is higher than that of individual members in the open class of common nouns. Consequently, their collocation patterns in recurrent syntactic positions are more frequent. The frequency of recurrent collocations is one factor that favors grammaticalization processes (Diessel and Hilpert 2016). As part of this tendency, the higher the relative frequency of a candidate for grammaticalization in some class (e.g., clitics, common nouns) in some collocation (e.g., preverbally in the case of preverbal clitics), the more likely it is to grammaticalize. In Medieval Spanish and French, the relative frequency of third person pronouns is different to begin with in the 12th century (Section 5.2.1) and the variation continues and becomes clearer throughout the period covered in this study. It is currently impossible to tell the effect that prominence-conditioned clitic patterns themselves have had on the overall frequency of clitics. However, the trend is one in which the higher relative frequency of certain clitics to begin with (the Span- 
ish dative and French adverbial clitics) and the early occurrence of opposite tendencies in prominence-conditioned cliticization from the earliest stages precede a similar grammaticalization in adnominal marking. The early process in the clitic systems, as reflected in the extremely low relative frequency of adverbial clitics and use of leismo in Spanish, culminates with a typological differentiation: while some languages tend to use "special morphosyntactic devices" for prominent referents, others tend to use them for non-prominent referents.

This shift of such a tendency from clitic to adnominal marking, as illustrated with comparative diachronic data from two languages, might be partly explained by frequency effects in grammaticalization. The relative frequency of clitics as compared to the open class of nouns makes them more prone to grammaticalization in the first place (Haspelmath 2004). All else being equal, the more frequently prominence-conditioned cliticization is used, the more likely it becomes for its gradual shift to adnominal marking (if any) to take on the same trend. However, this alone cannot explain the lesser marking of the opposite prominence category (e.g., referentially non-prominent nouns that remain bare in a Dом language). Here it may prove fruitful to consider the possible effects of language processing on cross-linguistic variation and the tendency to morphologically reduce some but not all members of different subsystems (e.g., number-marking, prominence-marking, cf. Hawkins 2012). This approach is driven by constraints on language change that affect synchronic grammars (Haspelmath 2019). By hypothesis, this may add to the precedence of clitics hypothesis to explain the negative relation between PA and DOM, and consequently the bare noun/PA distribution. However, further research is required to determine whether more evidence can be adduced that supports such an account.

While the diachronic data comes from languages at opposite poles of prominence-marking continuum, the synchronic study reveals several languages that combine both tendencies to some extent. At face value, some of these may challenge the precedence of clitics hypothesis (e.g., Catalan with adverbial clitics and a pervasive pattern of established ром in non-standard varieties, see Escandell-Vidal 2009; Rigau 1982). However, the precedence of clitics is most probably not the only factor that determines the distribution of bare nouns and PA, among other phenomena of prominence-conditioned morpho-syntax. Other factors may include long-term contact with other languages (Escandell-Vidal 2009), word order typology (Carlier and Lamiroy 2014) and general factors in language processing (Hawkins 2012).

Further research is required to determine the contribution of individual factors and the place of the clitic system in this process. 


\section{Acknowledgements}

Research for this study was partly supported by the Mandel School for Advanced Studies in the Humanities (Hebrew University of Jerusalem) and by a Graduate Center Fellowship (City University of New-York). I thank two anonymous reviewers for constructive comments on this paper. For other feedback, I thank the organizers and audience at the "Bare nouns vs. partitive articles: disentangling functions" workshop (Zurich, SLE 2017). My thanks are also due to Cyril Aslanov and Eitan Grossman whose classes (2010-2014) formed the basis for the approach adopted in this study. Thank you also to Christina Tortora, Jason Kandybowicz, Matthias Heinz and Richard Waltereit for comments during various stages of research. Of course, any errors and inaccuracies are my own.

\section{Appendixes}

\section{Appendix 1. Distribution of Partitive Article and Differential Object Marking per Genealogical Group}

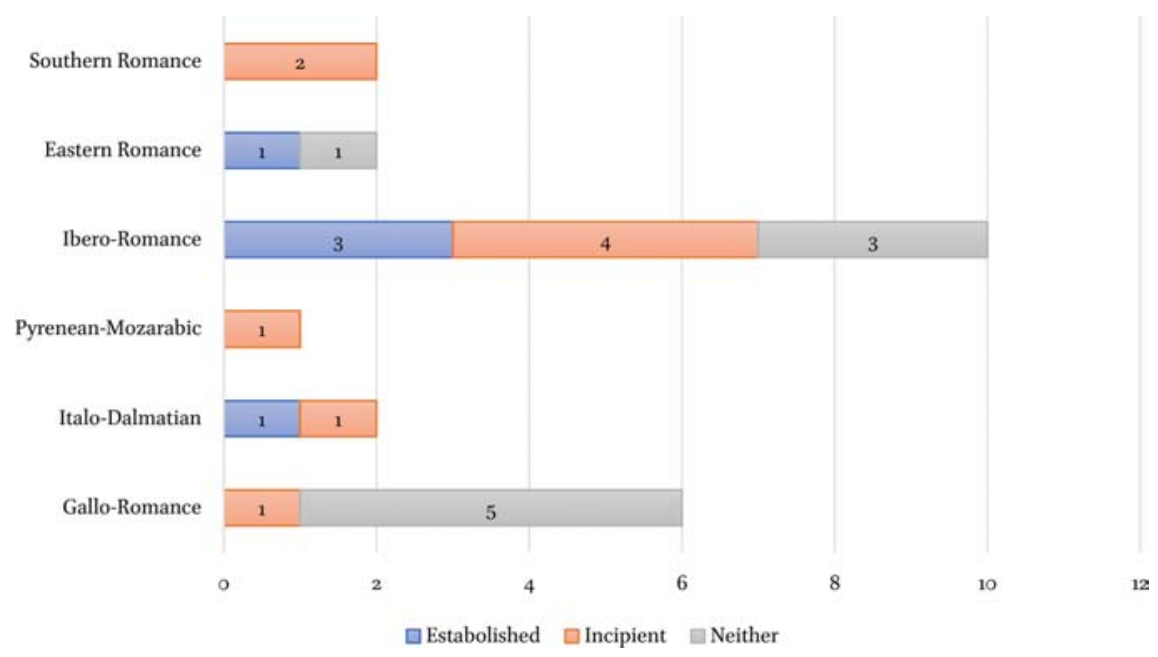

FIGURE 3.7 Distribution of DOM patterns per genealogical subgroup 


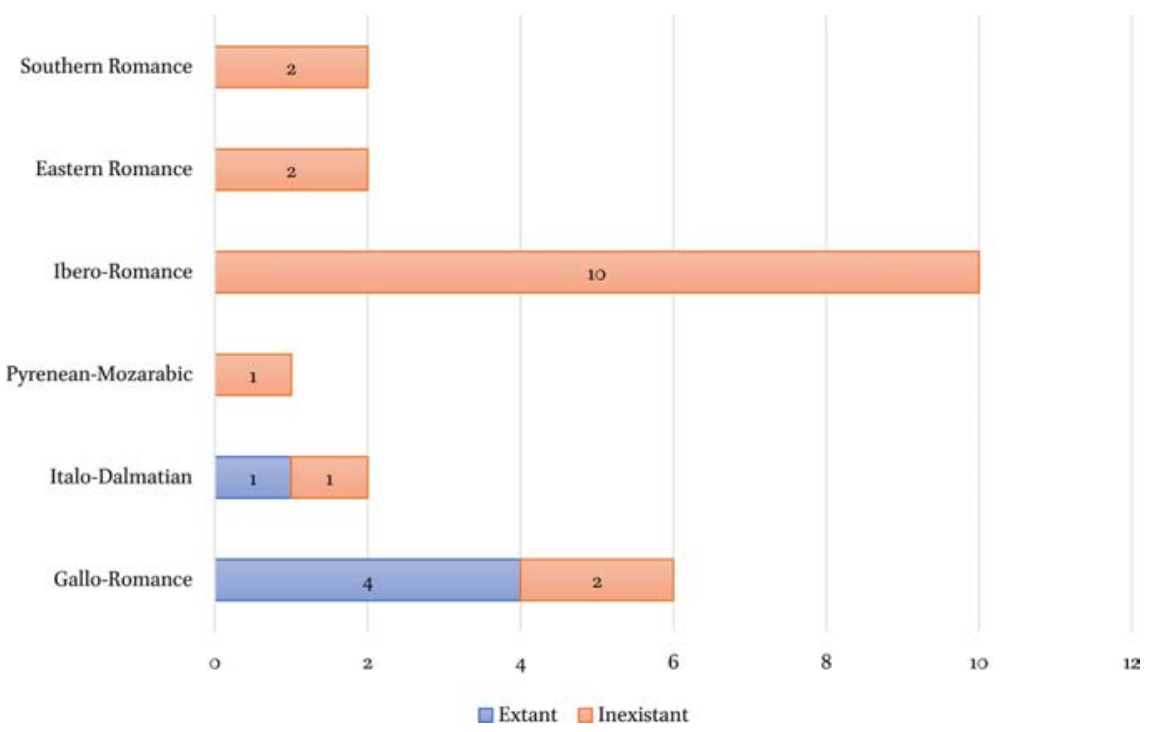

FIGURE 3.8 Distribution of partitive article patterns per genealogical subgroup

\section{Appendix 2}

TABLE 3.8 Distribution of Prominence-Conditioned Adnominal Patterns in European Romance

(Pro)nominal marking

Low- Differential Object Marking

prominence

$\begin{array}{llcccc}\begin{array}{l}\text { Partitive } \\ \text { article }\end{array} & \begin{array}{l}\text { De-plural } \\ \text { indefinites }\end{array} & \text { Exists? } & \text { Pronouns } & \text { Proper } & \begin{array}{l}\text { Kinship Human } \\ \text { term }\end{array}\end{array}$

\begin{tabular}{lcccccc}
\hline Daco-Romanian & & & $\checkmark$ & $\checkmark$ & $\checkmark$ \\
Istro-Romanian & & $\checkmark$ & $\checkmark$ & $\checkmark$ \\
Italian & & $\checkmark$ & $\checkmark$ & \\
Sicilian & $\checkmark$ & $\checkmark$ & & \\
Emilian & $\checkmark$ & & & \\
Ligurian & $\checkmark$ & $\checkmark$ & & & \\
French & $\checkmark$ & & & & \\
Arpitan & & & & \\
Ladin & & & & $\checkmark$ & $\checkmark$ \\
Vallader & & & & $\checkmark$ \\
Catalan (Central) & & & $\checkmark$ & $\checkmark$ & $\checkmark$ \\
Valencian & & & $\checkmark$ & $\checkmark$ & $\checkmark$ & $\checkmark$
\end{tabular}


TABLE 3.8 Distribution of Prominence-Conditioned Adnominal Patterns (cont.)

(Pro)nominal marking

Low-

Differential Object Marking

prominence

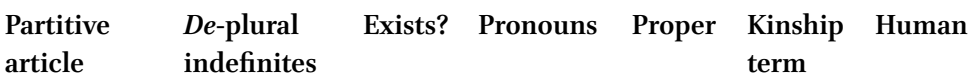

\begin{tabular}{|c|c|c|c|c|c|c|}
\hline Provençal & $\checkmark$ & & & & & \\
\hline Gascon & & $\checkmark$ & $\checkmark$ & & $\checkmark$ & \\
\hline $\begin{array}{l}\text { Asturian (western, } \\
\text { eastern) }\end{array}$ & $\checkmark$ & $\checkmark$ & $\checkmark$ & $\checkmark$ & $\checkmark$ & $\checkmark$ \\
\hline Extremaduran & $\checkmark$ & & & & & \\
\hline Spanish & & $\checkmark$ & $\checkmark$ & $\checkmark$ & $\checkmark$ & $\checkmark$ \\
\hline Galician & & $\checkmark$ & $\checkmark$ & & & \\
\hline Portuguese & & $\checkmark$ & $\checkmark$ & & & \\
\hline Aragonese & & $\checkmark$ & $\checkmark$ & & & \\
\hline Corsican & & $\checkmark$ & $\checkmark$ & $\checkmark$ & $\checkmark$ & \\
\hline Campidanese & & $\checkmark$ & $\checkmark$ & $\checkmark$ & $\checkmark$ & $\checkmark$ \\
\hline
\end{tabular}

TABLE 3.9 Distribution of Prominence-Conditioned Clitics in European Romance

\begin{tabular}{|c|c|c|c|c|}
\hline & Clitics & & & \\
\hline & Partitive & Locative & Leísmo & References \\
\hline Daco-Romanian & & & & (Corneliscu 200o; Hill 2013; David 2014) \\
\hline Istro-Romanian & & & & (Zegrean 2012) \\
\hline Italian & $\checkmark$ & $\checkmark$ & & (Genesini 2017; Iemmolo 2010) \\
\hline Sicilian & $\checkmark$ & $\checkmark$ & & (Messina 2007) \\
\hline Emilian & $\checkmark$ & $\checkmark$ & & (Ferretti 2007) \\
\hline Ligurian & $\checkmark$ & $\checkmark$ & & (Costa 1993) \\
\hline French & $\checkmark$ & $\checkmark$ & & (Bruxelles et al. 2016) \\
\hline Arpitan & $\checkmark$ & $\checkmark$ & & (Arpitana 2011) \\
\hline Ladin & $\checkmark$ & & & (Chiocchetti 2001; Stark 2015) \\
\hline Vallader & & & & $\begin{array}{l}\text { (Caduff, Caprez and Darms 2009; } \\
\text { Tscharner 2013)(Acadèmia Valenciana } \\
\text { de la Llengua 2006; Escandell-Vidal 20o9) }\end{array}$ \\
\hline Catalan (Central) & $\checkmark$ & $\checkmark$ & & $\begin{array}{l}\text { (Acadèmia Valenciana de la Llengua } \\
\text { 2006) }\end{array}$ \\
\hline Valencian & $\checkmark$ & $\checkmark$ & & $\begin{array}{l}\text { (Acadèmia Valenciana de la Llengua } \\
\text { 2006; Escandell-Vidal 2009) }\end{array}$ \\
\hline Provençal & $\checkmark$ & $\checkmark$ & & (Mistral and Ronjat 1979) \\
\hline Gascon & $\checkmark$ & $\checkmark$ & & (Rohlfs 1971, 321) \\
\hline
\end{tabular}


TABLE 3.9 Distribution of Prominence-Conditioned Clitics (cont.)

Clitics

Partitive Locative Leísmo References

\begin{tabular}{|c|c|c|c|c|}
\hline \multicolumn{3}{|l|}{$\begin{array}{l}\text { Asturian (west- } \\
\text { ern, eastern) }\end{array}$} & $\checkmark$ & (Asturiana 2001) \\
\hline Extremaduran & & & & (Quiles Casas 2006) \\
\hline Spanish & & & $(\checkmark)$ & (Eberenz 2008; Fernández-Ordóñez 2001) \\
\hline Galician & & & $(\sqrt{ })$ & $\begin{array}{l}\text { (Cidrás Escáneo 2006; Humanidades } \\
\text { 2015) }\end{array}$ \\
\hline Portuguese & & & & (Schwenter 2014) \\
\hline Aragonese & $\checkmark$ & $\checkmark$ & & (Plaza Boya 199o) \\
\hline Corsican & & $\checkmark$ & & (Batti 20o9; Neuburger and Stark 2014) \\
\hline Campidanese & $\checkmark$ & $\checkmark$ & & (Holtus 1988; Mondo-Sardegna 2014) \\
\hline
\end{tabular}

\section{References}

\section{Grammars and Corpora}

Académia de la Lingua Asturiana. 2001. Gramática de la Llingua Asturiana, 3rd ed. Oviedo: Academia de la Llingua Asturiana (ALA). http://www.academiadelallingua .com/wp-content/uploads/2014/10/Gramatica_Llingua.pdf.

Acadèmia Valenciana de la Llengua. 2006. "Gramàtica Normativa Valenciana." Col.lecció Textos Normatius 2, 410.

Alliance Culturèla Arpitana. 2011. "Lo Trèsor Arpitan.” Accessed on February 9, 2016. http://www.arpitan.eu/Tresor.

Anglade, Joseph. 1934. Grammaire élémentaire de l'ancien français. $5^{\text {th }}$ ed. Paris: Armand Colin.

Atlas Sintattico d'Italia (Syntactic Atlas of Italy). University of Padua, U. of V. 2011. Retrieved from http://asit.maldura.unipd.it

Batti, G. 2009. "Grammaire corse." Retrieved September 22, 2015, from http://gbatti -alinguacorsa.pagesperso-orange.fr/grammaire/grammaire.htm.

Bruxelles, Sylvie, Etienne, Carole, Jouin-Chadron, Emilie, Lascar, Justine, and TestonBonnard, Sandra. 2016. CLAPI. http://clapi.ish-lyon.cnrs.fr/.

Caduff, Renzo, Uorschla N. Caprez, and Georges Darms. 20o9. Grammatica per l'instrucziun dal rumantsch grischun. Freiburg: Department of Romance lanuages and literature.

Cédille, E.G.-E.L. 2016. Base de Français Médiéval—Old French Corpus. Retrieved from http://bfm.ens-lyon.fr/spip.php?article327 
Chiocchetti, Nadia, red. 20o1. Gramatica di Ladin Standard. 1st ed. San Martin de Tor: Istitut Cultural Ladin "Micura de Rü".

Costa, Carlo. 1993. Grammatica genovese, 2nd ed. Tigullio-Bacherontius. Retrieved September 11, 2019, from http://carlocosta.info/Grammatica_genovese.htm.

Cuétara Priede, Javier, and Concepción Company Company. eds. 2014. Manual de gramática histórica, 3rd ed. Mexico City: Facultad de Filosofia y Letras, Universidad Nacional Autónoma de México.

Española, R.A. 2016a. Corpus de referencia del español actual. Retrieved from http:// www.rae.es.

Española, R.A. 2016b. Corpus diacrónico del español. Retrieved from http://www.rae.es Ferretti, Denis. 2007. Grammatica Reggiana, 1-120. Ebook.

Genesini, Pietro. 2017. Grammatica italiana in rapidi schemi. Padova.

Humanidades, C.R.P. para a I. en. 2015. Corpus de Referencia do Galego Actual (CORGA). Retrieved from http://www.cirp.gal/corga.

Messina, Arturo. 2007. "Grammatica Sistematica della Lingua Siciliana." Retrieved April 26, 2015, from http://www.antoniorandazzo.it/parolesiracusane/files/grammatica -siciliana-ARTURO-MESSINA-2007.pdf.

Mistral, Frédéric, and Jules Ronjat. 1979. "Lou Tresor dóu Felibrige ou: dictionnaire provençale-français, vol. 3." Retrieved August 27, 2015, from http://www.eonet.ne.jp/ $\sim$ ogurisu/francais/sectoo21.html.

Mondo-Sardegna. 2014. Grammatica sardo-campidanese. Retrieved from http://www .mondosardegna.net/all-lang/download/download.php?LANG=ita\&a=viewPage\& cat=linguasarda.

Nagore Lain, Franco. 1986. El Aragones de Panticosa-Gramatica. Zaragoza: Instituto de estudios altoargoneses.

Sánchez-Marco, C., E. Bofias, T. Bassaganyas, A. Chandía, and J.M. Fontana. n.d. Medieval Spanish Corpus http://corptedig-glif.upf.edu/cqpweb/oldes/(OLDEs). Retrieved January $1,2016$.

Tscharner, Gion. 2013. The grammatical Section of the Vallader-German, German-Vallader dictionary. Retrieved August 27, 2015, from http://www.udg.ch/dicziunari/files/ grammatica_vallader.pdf.

\section{Further references}

Aikhenvald, Alexandra Y. 2017. "A Typology of Noun Categorization Devices." In The Cambridge handbook of linguistic typology, edited by Alexandra Y. Aikhenvald and R.M.W. Dixon, 361-404. Cambridge: Cambridge University Press.

Aissen, Judith. 2003. "Differential Object Marking: Iconicity vs. Economy." Natural Language and Linguistic Theory 21: 435-483. https://doi.org/10.1023/A:1024109008573.

Auer, Peter. 2004. "Non-Standard Evidence in Syntactic Typology-Methodological Remarks on the Use of Dialect Data vs Spoken Language Data." In Dialectology Meets 
Typology: Dialect Grammar from a Cross-Linguistic Perspective, edited by Bernd Kortmann, 69-92. Berlin: de Gruyter.

Bárány, Andràs. 2018. Person, Case, and Agreement: The Morphosyntax of Inverse Agreement and Global Case Splits. Oxford: Oxford University Press.

Benincà, Paola, and Cecilia Poletto. 2005. "On some descriptive generalizations in Romance." In Handbook of comparative syntax, edited by Guglielmo Cinque and Richard Kayne, 221-258. New York, Oxford: Oxford University Press.

Beyssade, Claire. 2011. "Bare Nouns in Predicate Position in French." In Logic and Grammar, edited by Silvain Pogodalla, Myriam Quatrini and Christian Retoré (Lecture Notes in Computer Science), vol. 670o, 1-16. Berlin, Heidelberg: Springer. https://doi .org/10.1007/978-3-642-21490-5_1.

Bossong, Georg. 1982. "Historische Sprachwissenschaft und empirische Universalienforschung." Romanistisches Jahrbuch 33, no. 35: 17-51.

Bossong, Georg. 1985. Empirische Universalienforchung. Differentielle Objektmarkierung in den neuiranischen Sprachen. Tübingen: Gunter Narr Verlag. Tübingen: Gunter Narr Verlag.

Bossong, Georg. 1991. "Differential Object Marking in Romance and Beyond." In New Analyses in Romance Linguistics, edited by Douglas A. Kibbee and Dieter Wanner, 143-170. Amsterdam, Philadelphia: John Benjamins.

Bossong, Georg. 2008. Die romanischen Sprachen: eine vergleichende Einführung. Thübingen: Helmut Buske Verlag.

Boye, Kasper, and Peter Harder. 2012. "A usage-based theory of grammatical status and grammaticalization." Language 88, no. 1:1-44.

Bybee, Joan L. 20o6. "From Usage to Grammar: The Mind's Response to Repetition." Language 82, no. 4: 711-733. https://doi.org/10.1353/lan.2006.o186.

Campbell, Lyle. 2000. "What's Wrong with Grammaticalization?" Language Sciences 23, no. 2-3: 113-161. https://doi.org/10.1016/so388-ooo1(oo)ooo19-x.

Carlier, Anne. 2007. "From Preposition to Article: The Grammaticalization of the French Partitive." Studies in Language 31, no. 1: 1-49.

Carlier, Anne, and Béatrice Lamiroy. 2014. "The Grammaticalization of the Prepositional Partitive in Romance." In Partitive Cases and Related Categories, edited by Silvia Luraghi and Tuomas Huomo, 477-522. Berlin: de Gruyter.

Cidrás Escáneo, Francisco A. 20o6. "Sobre o uso da preposición a con oD en galego." Verba 33: 147-174. http://hdl.handle.net/10347/3458.

Cornilescu, Alexandra. 200o. "Notes on the Prepositional Accusative in Romanian." Bucharest Working Papers in Linguistics II, no. 1: 91-106.

Dalrymple, Mary, and Irina Nikolaeva. 2011. Objects and Information Structure. Cambridge: Cambridge University Press.

David, Oana A. 2014. "Subjectification in the Development of Clitic Doubling: A Diachronic Study of Romanian and Spanish." In Proceedings of the Fortieth Annual Meet- 
ing of the Berkeley Linguistics Society, edited by Herman Leung et al., vol. 40, 42-61. Berkley: Berkeley Linguistics Society.

De Hoop, Helen, and Andrej L. Malchukov. 2008. "Case-Marking Strategies." Linguistic Inquiry 39, no. 4: 565-587. https://doi.org/10.1162/ling.20o8.39.4.565.

Diessel, Holger, and Martin Hilpert. 2016. "Frequency Effects in Grammar." In Linguistics: Oxford Research Encyclopedias, edited by Mark Aronoff. Oxford: Oxford University Press. https://doi.org/10.1093/acrefore/9780199384655.013.120.

Diez, Friedrich C. 1844. Grammatik der romanischen Sprachen, 3rd ed. Bonn: E. Weber.

Dobrovie-Sorin, Carmen. This volume. "Negation, des-Indefinites in French and Bare Nouns across Languages."

Dobrovie-Sorin, Carmen, and Brenda Laca. 2003. "Les noms sans déterminant dans les langues romanes." In Les Langues Romanes. Problèmes de La Phrase Simple, edited by Danièle Godard, $235^{-281}$. Paris: CNRs.

Eberenz, Rolf. 2008. “'Ninguno quiere del agua turbia beber': sobre construcciones partitivas y su representación en algunos géneros textuales del español preclásico." In Sintaxis histórica del español y cambio lingüistico: Nuevas perspectivas desde las Tradiciones Discursivas, edited by Johannes Kabatek, 151-172. Madrid: Iberoamericana/Vervuert.

Echenique Elizondo, Maria Teresa. 1981. "El sistema referencial en español antiguo: Leísmo, laísmo y loísmo." Revista de Filología Española LXI, no. 1: 113-157.

Enrique-Arias, Andrés, and Miriam Bouzouita. 2013. "La frecuencia textual en la evolución histórica de los clíticos pronominales en español." Iberoromania 77: 29-46.

Escandell Vidal, Victoria. 2007. "Acusatiu preposicional i dislocació amb clític." Caplletra. Revista Internacional de Filologia 42: 185-218. https://doi.org/10.7203/caplletra .42 .4823 .

Fagard, Benjamin, and Alexandru Mardale. 2014. "Non, mais tu l' as vu à lui? Analyse(s) du marquage différentiel de l'objet en français." Verbum 26, no. 1: 145-17o. https:// halshs.archives-ouvertes.fr/halshs-01121653/document.

Fedden, Sebastian, and Greville G. Corbett. 2017. "Gender and Classifiers in Concurrent Systems: Refining the Typology of Nominal Classification." Glossa 2, no. 1: 1-47. doi:10.5334/gjgl.177.

Fernández-Ordóñez, Inés Rosa. 2001. "Hacia una dialectología histórica: reflexiones sobre la historia del leísmo, el laísmo y el loísmo." Boletín de La Real Academia Española 81, no. 284: 389-464. http://hdl.handle.net/10486/66o431.

Fontana, Joseph. M. 1993. "Phrase Structure and the Syntax of Clitics in the History of Spanish." PhD Diss., University of Pennsylvania Philadelphia.

Franchi, Ghjuvan Ghjaseppu. 200o. Puntelli di grammatica. Ajaccio: C.R.D.P de Corse.

Gabriel, Christoph, and Esther Rinke. 2010. "Information Packaging and the Rise of Clitic Doubling in the History of Spanish." In Language, Context and Cognition: 
Diachronic Studies on Information Structure, edited by Gisella Ferraresi and Rosemarie Lühr, 63-86. Berlin: de Gruyter.

Gerards, David Paul, and Elisabeth Stark. This volume. "Why 'Partitive Articles' Do Not Exist in (Old) Spanish."

Giusti, Giuliana. This volume. "A Protocol for Indefinite Determiners in Italian and Italo-Romance."

Greenberg, Joseph Harold. 1978. "How does a Language Acquire Gender Markers.” Universals of Human Language 3: 47-82.

Harris, Alice, and Lyle Campbell. 1995. Historical Syntax in cross-linguistic perspective. Cambridge: Cambridge University Press.

Harris-Northall, Ray. 2005. "The Count/Non-Count Distinction in Castilian: Evidence for its Place and Function in the Medieval Language." In Studies on Ibero-Romance Linguistics Dedicated to Ralph Penny, edited by Roger Wright and Peter Rricketts, 167-185. Newark, Delaware: Juan de La Cuesta.

Haspelmath, Martin. ed. 2004. "Explaining the Ditransitive Person-Role Constraint: A Usage Based Account." Constructions 2: 1-49. (free online journal university of Düsseldorf).

Haspelmath, Martin. 2010. "Comparative Concepts and Descriptive Categories in Crosslinguistic Studies." Language 86, no. 3: 663-687. https://doi.org/10.1353/lan .2010 .0021 .

Haspelmath, Martin. 2013. "Argument Indexing: A Conceptual Framework for the Syntactic Status of Bound Person Forms." In Languages across Boundaries: Studies in Memory of Anna Siewierska, edited by Dik Bakker and Martin Haspelmath, 197-226. Berlin: de Gruyter.

Haspelmath, Martin. 2015. “Descriptive Scales versus Comparative Scales." In Scales and Hierarchies: A Cross-Disciplinary Perspective, edited by Ina Bornkessel-Schlesewsky, Andrej L. Malchukov and Marc Richards, 45-58. Berlin: de Gruyter.

Haspelmath, Martin. 2018. "Role-Reference Association and the Explanation of Argument Coding Splits (draft)." doi: 10.5281/zenodo.1163411.

Haspelmath, Martin. 2019. "Explaining Grammatical Coding Asymmetries: Form-Frequency Correspondences and Predictability." (submitted) https://www.academia .edu/375106o1/Explaining_grammatical_coding_asymmetries_Form-frequency_co rrespondences_and_predictability.

Hawkins, John A. 2012. "Patterns of Asymmetry in Argument Structure across Languages." In Argument Structure and Grammatical Relations: A Crosslinguistic Typology 126, edited by Pirkko Suihkonen, Bernhard Comrie and Valery Solovyev, 133-150. Amsterdam: John Benjamins.

Hill, Virginia. 2013. “The Direct Object Marker in Romanian: A Historical Perspective." Australian Journal of Linguistics 33, no. 2: 140-151.

Hill, Virginia, and Liliane Tasmowski. 2008. "Romanian Clitic Doubling: A View from 
Pragmatics-Semantics and Diachrony." Clitic Doubling in the Balkan Languages 130: 135-163. https://doi.org/10.1075/la.130.1ohil.

Holtus, Günter. 1988. Italienisch, Korsisch, Sardisch. Tübingen: de Gruyter.

Hopper, Paul J., and Sandra A. Thompson. 1980. "Transitivity in Grammar and Discourse." Language 56, no. 2: 251-299.

Iemmolo, Giorgio. 2010. "Topicality and Differential Object Marking: Evidence from Romance and Beyond." Studies in Language 34, no. 2: 239-272. https://doi.org/10 $.1075 /$ sl.34.2.o1iem.

Ihsane, Tabea. 2005. "On the Structure of French $d u / d e s$ 'of. the' Constituents." Generative Grammar in Geneva 4: 195-225.

Ihsane, Tabea. 2008. The Layered DP in French. Form and Meaning of French Indefinites. Amsterdam, Philadelphia:John Benjamins.

Ihsane, Tabea. 2013. "On Pronominalization in French and the Structure of Nominal Expressions." Syntax 16, no. 3: 217-249. https://doi.org/10.1111/synt.12003.

Ihsane, Tabea. This volume. "Telicity, Specificity, and Complements with a "Partitive Article" in French."

Kabatek, Johannes. 2013. "Areal pathways of bare nouns in Romance." Workshop Mass and Count in Romance and Germanic Languages. University of Zürich.

Kabatek, Johannes. 2014. "Some Remarks on Partitive Determiners in Romance." International Workshop about Partitivity in Romance and beyond. University of Zürich.

Kabatek, Johannes, and Albert Wall. eds. 2013. New Perspectives on Bare Noun Phrases in Romance and Beyond [Studies in Language Companion Series 141]. Amsterdam, Philadelphia: John Benjamins. https://doi.org/10.1075/slcs.141.

Koptjevskaja-Tamm, Maria. 20o9. "A lot of Grammar with a Good Portion of Lexicon towards a Typology of Partitive and Pseudo-Partitive Nominal Constructions." In Form and Function in Language Research: Papers in Honour of Christian Lehmann, edited by Johannes Helmbrecht et al., 329-346. Berlin: de Gruyter.

Körner, Karl-Hermann. 1981. “'Teilungsartikel' im Französischen und 'präpositionaler Akkusativ' im Spanischen. Komplementäre Lösungen des gleichen syntaktischen Problems." In Sprache: Formen und Strukturen. Akten des 15 Ling. Koll., 151-16o. Thübingen.

Körner, Karl-Hermann. 1987. Korrelative Sprachtypologie. Die zwei Typen romanischer Syntax. Stuttgart: Steiner-Verlag-Wiesbaden-GmbH.

Langacker, Ronald W. 1987. Foundations of Cognitive Grammar: Theoretical Prerequisites, vol. 1. Stanford, CA: Stanford University Press.

Ledgeway, Adam. 2012. From Latin to Romance: Morphosyntactic Typology and Change. Oxford: Oxford University Press. https://doi.org/10.1093/acprof:oso/978o199584376 .001.0001.

Lewis, M. Paul, Gary F. Simons, and Charles D. Fennig. eds. 2015. Ethnologue: Languages of the World, 18th ed. Dallas, Texas: sIL International. 
Lorente, Antonio, and José Mondéja. 1974. "La conjugación objetiva en español." Revista Española de Lingüística 4, no. 1: 1-6o.

Luraghi, Silvia. 2012. "Partitives and Differential Marking of Core Arguments: A CrossLinguistic Survey." http://attach.matita.net/silvialuraghi/Partitives.pdf. Retrieved November 23, 2015, from http://attach.matita.net/silvialuraghi/Partitives.pdf.

Mardale, Alexandru. 2008. "Notes on Bare Plurals and Differential Object Marking in Romance." Studii Si Cercetari Lingvistice 59, no. 2: 411-424. https://halshs.archives -ouvertes.fr/halshs-oo556193.

Meier, Harri. ed. 1948. "Sobre as origens do acusativo preposicional nas lìnguas românicas." In Ensaios de filologia românica, 115-164. Lisboa: Revista da Portugal.

Meillet, Antoine. 1912. "L' évolution des formes grammaticales." Scientia 6, no. 12: $384 \mathrm{ff}$.

Miestamo, Matti. 2014. "Partitives and negation: A cross-linguistic survey." In Partitive cases and related categories (Empirical Approaches to Language Typology, vol. 54), edited by Silvia Luraghi und Tuomas Huumo, 63-86. Berlin: de Gruyter.

Neuburger, Kathrin A., and Elisabeth Stark. 2014. "Differential Object Marking in Corsican: Regularities and Triggering Factors." Linguistics 52, no. 2: $365-389$. https://doi .org/10.1515/ling-2013-0o66.

Pescarini, Diego. 2005. “The Morphology of Romance Clitic Clusters." In Proceedings of CamLing 2005, 237-146. Cambridge: Institute of Language Research.

Pinchon, Jacqueline. 1972. "Histoire d'une norme, emploi des pronoms 'lui', 'eux', 'elle(s)', 'en', 'y'.' Langue française 16, no. 1: 74-87. https://doi.org/10.3406/lfr.1972.57 05.

Plaza Boya, A. 199o. "El dialecto del Valle de Benasque (Comarca de Castejón de Sos). Bases para una morfosintaxis." Alazet 2: 155-236.

Quiles Casas, Carlos. 20o6. "Gramatica Cantabru-Estremenu." Accessed April 16, 2020. https://www.iventia.com/gramatica_cantabru_estremenu_2.pdf.

Rigau, Gemma. 1982. "Inanimate Indirect Object in Catalan." Linguistic Inquiry 13, no. 1: 146-15o.

Rohlfs, Gerhard. 1969. Grammatica storica della lingua italiana e dei suoi dialetti: sintassi e formazione delle parole. Torino: Piccola Biblioteca.

Rohlfs, Gerhard. 1971. "Autour de l' accusatif prépositionnel dans les langues romanes: concordances et discordances." Revue Linguistique Romane 35: 312-334.

Sánchez Lancis, Carlos E. 1992. "Adverbio Pronominal Y como Dativo Inanimado en Español Medieval." In Actas del II Congreso Internacional de Historia de la Lengua española, vol. 1, edited by Manuel Ariza Viguera, 795-804. Pabellón de España.

Schikowski, Robert, and Giorgio Iemmolo. 2015. "Commonalities and Differences between Differential Object Marking and Indexing." University of Zürich, Department of Comparative Linguistics, ${ }^{1-35}$. http://www.ivs.uzh.ch/schikowski/publications/ 2015-dom-vs-doi.pdf.

Schwenter, Scott A. 2014. "Two Kinds of Differential Object Marking in Portuguese and 
Spanish." In Portuguese-Spanish Interfaces:Diachrony, synchrony, and contact, edited by Patrícia Amaral and Ana Maria Carvalho, 239-26o. Amsterdam, Philadelphia: John Benjamins.

Seifart, Frank. 2010. "Nominal classification." Language and Linguistics Compass 4, no. 8: 719-736. https://doi.org/10.1111/j.1749-818X.2010.00194.x.

Senft, Gunter. 2007. "Nominal classification." In The Oxford handbook of cognitive linguistics, edited by D. Geeraerts and H. Cuyckens, 676-696. Oxford: Oxford University Press. http://hdl.handle.net/11858/oo-oo1M-oooo-oo13-1C61-3.

Seržant, Ilja A., and Witzlack-Makarevich, Alena. 2018. Diachrony of differential argument marking. Berlin: Language Science Press. https://doi.org/10.5281/zenodo.1219 168.

Silverstein, Michael. 1976. "Hierarchy of features and Ergativity." In Grammatical Categories in Australian Languages, edited by R.M.W. Dixon, 163-272. New Jeresey: Humanities Press.

Stark, Elisabeth. 2005. "Typological Correlations in Nominal Determination in Romance." In Specificity and the Evolution/Emergence of Nominal Determination Systems in Romance, edited by Klaus Von Heusinger, Georg A. Kaiser and Elisabeth Stark, 123-138. Konstanz: Universität Konstanz.

Stark, Elisabeth. 2007. “Gender, Number, and Indefinite Articles: About the Typological Inconsistency of Italian.” In Nominal determination: Typology, Context Constraints, and Historical Emergence, edited by Elisabeth Stark, Elisabeth Leiss and Werner Abraham, 49-71. Amsterdam, Philadelphia: John Benjamins.

Stark, Elisabeth. 2009. "Neutrum Und individuum: Zentrale Konzepte in der Grammatik der romanischen Sprachen." Romanische Forschungen 121, no. 3: 273319 .

Stark, Elisabeth. 2015. "Partitivity in Romance and beyond: Introduction." https://www .rose.uzh.ch/de/seminar/wersindwir/mitarbeitende/stark/workshop.html.

Stark, Elisabeth. 2016. "Nominal Morphology and Semantics-Where's Gender (and 'Partitive Articles') in Gallo-Romance?" In Proceedings of the VII Nereus International Workshop: "Clitic Doubling and other issues of the syntax/semantic interface in Romance DPs", edited by Susann Fischer and Mario Navarro, Arbeitspapier 128, 131-149.

Storto, Gianluca. 2003. "On the Status of the Partitive Determiner in Italian." In Romance Languages and Linguistic Theory 2001: Selected Papers from Going Romance 2001, edited by Joseph Quer et al., 315-330. Amsterdam: John Benjamins.

Strobel, Thomas, and Elvira Glaser. This volume. "The Rise and Fall of Partitive Markers in Some Germanic Varieties.”

Sweetser, Eve E. 1988. "Grammaticalization and Semantic Bleaching." In Annual Meeting of the Berkeley Linguistics Society, vol. 14, 389-405. http://dx.doi.org/10.3765/bls .v14io.1774. 
Tuten, Donald N., Enrique Pato, and Ora R. Schwarzwald. 2016. "Spanish, Astur-Leonese, Navarro-Aragonese, Judaeo-Spanish." In The Oxford Guide to the Romance Languages: Volume 1, edited by Adam Ledgeway and Martin Maiden, 382-410. Oxford: Oxford University Press.

Von Fintel, Kai. 1995. "The formal semantics of grammaticalization." In Proceedings NELS 25, pp. 175-19o. Amherst: University of Massachusetts.

Von Heusinger, Klaus, and Sofiana I. Chiriacescu. 20o9. "Definite 'Bare' Nouns and PeMarking in Romanian." In Proceedings of the IV Nereus International Workshop "Definiteness and DP Structure in Romance Languages", edited by Maria Theresa Espinal, Manuel Leonetti and Louise McNally, Arbeitspapier 124, 63-82. Konstanz: Universität Konstanz: Fachbereich Sprachwissenschaft.

Von Heusinger Klaus, and Georg A. Kaiser 2005. "The Evolution of Differential Object Marking in Spanish." In Proceedings of the Workshop: Specificity and the Evolution/ Emergence of Nominal Determination Systems in Romance, edited by Klaus Von Heusinger, Georg A. Kaiser and Elisabeth Stark, Arbeistspapier 119, 33-69. Unversität Konstanz: Fachbereich Sprachwissenschaft.

Zegrean, Iulia-Giorgiana. 2012. Balkan Romance: Aspects on the Syntax of Istro-Romanian. Università Ca'Foscari Venezia. http://hdl.handle.net/10579/1166. 